\title{
The role of anthropogenic and natural factors in shaping the geochemical evolution of groundwater in the Subei Lake basin, Ordos energy base, Northwestern China
}

\author{
Fei Liu ${ }^{\text {a,b }}$, Xianfang Song ${ }^{\mathrm{a}, *}$, Lihu Yang ${ }^{\mathrm{a}}$, Dongmei Han ${ }^{\mathrm{a}}$, Yinghua Zhang ${ }^{\mathrm{a}}$, Ying Ma ${ }^{\mathrm{a}}$, Hongmei Bu ${ }^{\mathrm{a}}$

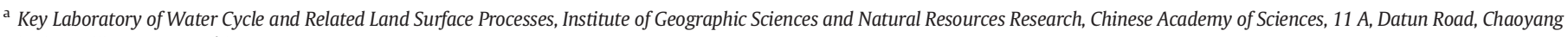 \\ District, Beijing 100101, China \\ ${ }^{\mathrm{b}}$ University of Chinese Academy of Sciences, Beijing 100049, China
}

\section{H I G H L I G H T S}

- Rock weathering predominates the evolution of groundwater chemistry.

- Human activities affected the evolution of groundwater chemistry significantly.

- Anthropogenic factors were identified as two categories.

- Large-scale groundwater pumping caused the obvious change of hydrochemical facies.

- Local hydrogeologic settings and flood irrigation controlled nitrate contamination.

\section{A R T I C L E I N F O}

\section{Article history:}

Received 4 July 2015

Received in revised form 11 August 2015

Accepted 11 August 2015

Available online 24 August 2015

Editor: D. Barcelo

\section{Keywords:}

Groundwater chemistry

Anthropogenic activities

Natural processes

Groundwater pumping

Ordos energy base

\footnotetext{
* Corresponding author.

E-mail address: songxf@igsnrr.ac.cn (X. Song).
}

G R A P H I C A L A B S T R A C T

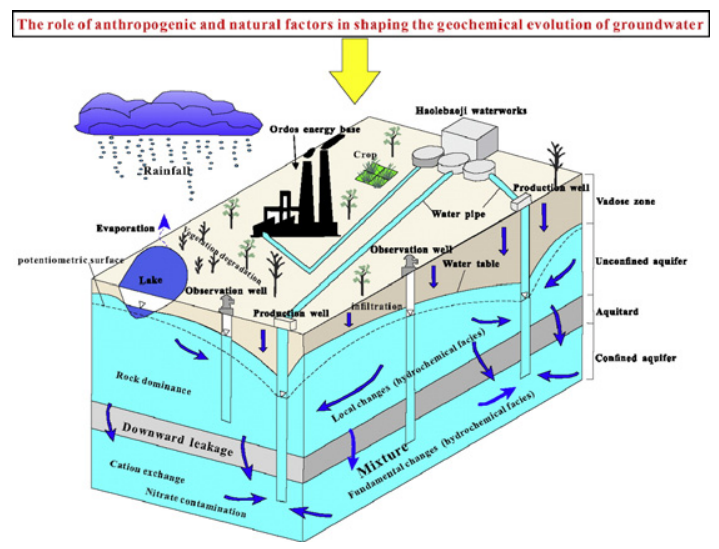

\section{A B S T R A C T}

Groundwater resources are increasingly exploited for industrial and agricultural purposes in many arid regions globally, it is urgent to gain the impact of the enhanced anthropogenic pressure on the groundwater chemistry. The aim of this study was to acquire a comprehensive understanding of the evolution of groundwater chemistry and to identify the impact of natural and anthropogenic factors on the groundwater chemistry in the Subei Lake basin, Northwestern China. A total of 153 groundwater samples were collected and major ions were measured during the three campaigns (August and December 2013, May 2014). At present, the major hydrochemical facies in unconfined groundwater are $\mathrm{Ca}-\mathrm{Mg}-\mathrm{HCO}_{3}, \mathrm{Ca}-\mathrm{Na}-\mathrm{HCO}_{3}, \mathrm{Na}-\mathrm{Ca}-\mathrm{HCO}_{3}, \mathrm{Na}-\mathrm{HCO}_{3}, \mathrm{Ca}-\mathrm{Mg}-\mathrm{SO}_{4}$ and $\mathrm{Na}-\mathrm{SO}_{4}-$ $\mathrm{Cl}$ types, while the main hydrochemical facies in confined groundwater are $\mathrm{Ca}-\mathrm{Mg}-\mathrm{HCO}_{3}, \mathrm{Ca}-\mathrm{Na}-\mathrm{HCO}_{3}, \mathrm{Na}-\mathrm{Ca}-$ $\mathrm{HCO}_{3}, \mathrm{Ca}-\mathrm{HCO}_{3}$ and $\mathrm{Na}-\mathrm{HCO}_{3}$ types. Relatively greater seasonal variation can be observed in the chemical constituents of confined groundwater than that of unconfined groundwater. Rock weathering predominates the evolution of groundwater chemistry in conjunction with the cation exchange, and the dissolution/precipitation of gypsum, halite, feldspar, calcite and dolomite are responsible for the chemical constituents of groundwater. Anthropogenic activities can be classified as: (1) groundwater overexploitation; (2) excessive application of fertilizers in agricultural areas. Due to intensive groundwater pumping, the accelerated groundwater mineralization 
resulted in the local changes in hydrochemical facies of unconfined groundwater, while the strong mixture, especially a large influx of downward leakage from the unconfined aquifer into the confined aquifer, played a vital role in the fundamental variation of hydrochemical facies in confined aquifer. The nitrate contamination is mainly controlled by the local hydrogeological settings coupled with the traditional flood irrigation. The deeper insight into geochemical evolution of groundwater obtained from this study can be beneficial to improving groundwater management for sustainable development in the rapidly industrialized areas.

(c) 2015 Elsevier B.V. All rights reserved.

\section{Introduction}

Groundwater is of great importance for drinking, irrigation and industry in semiarid and arid regions and even acts as the only available resource to sustain economic development and ensure water security of local communities in the areas where available surface water resource is scarce (Huang et al., 2013; Lawrence et al., 2000; Liu et al., 2015). On one hand, a variety of human activities such as drinking, irrigation and industrial use are supported by groundwater; on the other hand, groundwater plays a vital role in the maintenance and restoration of ecosystems dependent on groundwater such as alluvial and rocky aquifers, hyporheic zones, springs and wetlands (Boulton, 2009; Hancock et al., 2005). It is well known that many important ecological processes can be disrupted by changes in groundwater chemistry (Amalfitano et al., 2014; Di Lorenzo et al., 2015; lepure et al., 2014). Therefore, a sustainable groundwater management strategy requires a deeper understanding of geochemical evolution of groundwater in order to guarantee reliable supply for all purposes.

The geochemical evolution of groundwater is largely determined by the natural factors (such as lithology, hydrogeological conditions, water-rock interaction etc.) and anthropogenic activities (such as agriculture, industry etc.) (Lin et al., 2012). A lot of researchers have devoted to examining the effect of natural processes and human pressure on the current situation of groundwater chemistry in arid and semiarid areas (He et al., 2012; Wang et al., 2013). Recently, some researchers have also focused on the impact of intensive groundwater pumping on the evolution of groundwater chemistry (Ammar et al., 2014; Carucci et al., 2012; Güler et al., 2012; Sbarbati et al., 2015). The Subei Lake basin is a good illustration of such areas where natural and anthropogenic processes significantly affect groundwater resources. It is representative of more than 400 lake basins with diverse sizes distributed in the Ordos artesian basin that contains the second largest coal reserves in China (Dai et al., 2006). During the industrialization process, the quantity and quality of groundwater resources have been affected to a large extent. In recent decades, more and more waterworks have been built in some lake basins in order to meet the increasing demand of water resources with the fast development of Ordos energy base. Haolebaoji waterworks of the Subei Lake basin acts as an important source of water-supply for the exploitation of coal and development of related industries. The overexploitation of confined aquifer has caused a general piezometric decline resulting in drying up of most artesian wells as well as groundwater quality degradation (Wang et al., 2010). More importantly, the intensive groundwater pumping could significantly influence the hydrodynamics and hydrochemistry of the groundwater system. If this continues, it may cause a series of negative impacts on the groundwater-dependent ecosystem around these lakes. Despite the importance of the groundwater resource, basic information on the hydrological parameters and the geochemical behavior of the groundwater system is often lacking to assess its sustainability. So it is necessary to identify the impact of groundwater withdrawal on the geochemical evolution of groundwater.

The aim of the study is to investigate the Subei Lake basin where the confined aquifer is heavily exploited in order to refine the hydrodynamic continuity inside the aquifer system and to constrain the dominant geochemical processes controlling the changes in groundwater chemistry. These processes were identified using integrated geochemical methods applied to physico-chemical data. The main objectives are to: (1) investigate the geochemical evolution of groundwater in the Subei Lake basin based on the comparison of hydrochemical data variations; (2) identify the impact of natural factors and anthropogenic activities on the groundwater chemistry. The results will be beneficial to improving groundwater management for sustainable development in the rapidly industrialized areas, and to revealing the negative impacts of industrialization on the groundwater. In addition, the results obtained from this study can be an important reference on a national scale to meet the challenge of the water resources management in rapidly industrialized areas occurring in China.

\section{Study area}

\subsection{Physiography}

The Subei Lake basin almost covers an area of $400 \mathrm{~km}^{2}$ in the northern part of the Ordos artesian basin, Northwestern China, extending between longitudes of $108^{\circ} 51^{\prime} 24^{\prime \prime}-109^{\circ} 08^{\prime} 40^{\prime \prime} \mathrm{E}$ and latitudes of $39^{\circ} 13^{\prime}$ $30^{\prime \prime}-39^{\circ} 25^{\prime} 40^{\prime \prime} \mathrm{N}$ (Fig. 1). The climate is typically continental semi-arid to arid monsoon, characterized by hot summer and extremely cold winter. According to meteorological data from 1985 to 2008 collected at the Wushenzhao weather station, the average monthly temperature varied from $-11.5^{\circ} \mathrm{C}$ in January to $21.9^{\circ} \mathrm{C}$ in July. The mean annual precipitation was $324.3 \mathrm{~mm} \mathrm{yr}^{-1}$, and a majority of the precipitation falls in the form of rain during the monsoon from June to August, when precipitation accounted for more than $63.6 \%$ of annual precipitation. The mean annual pan evaporation was $2349.1 \mathrm{~mm} \mathrm{yr}^{-1}$, which far exceeded rainfall for the area. The topography of the west, east, north sides in the study area is relatively higher with elevations between 1370-1415 m above sea level, while its south side is slightly lower with altitudes between 1290-1300 m above sea level. The main water bodies are the Subei Lake and the Kuisheng Lake (Fig. 1). The Subei Lake is located in the low-lying center of the study area, which is an inland alkaline lake; while the Kuisheng Lake is also a perennial inland lake and it is located in northeastern corner of the study area, only covering two $\mathrm{km}^{2}$. In response to heavy rainfall events, groundwater and overland flow are the major recharge sources of the two inland lakes (Hou et al., 2006; Wang et al., 2010).

In the area, groundwater is heavily relied upon for agricultural, industrial and domestic purposes. The proportions of agricultural, industrial and domestic water demand were almost 30\%, $69 \%$ and $1 \%$, respectively in 2009 according to the unpublished hydrogeological report from Inner Mongolia Second Hydrogeology Engineering Geological Prospecting Institute. Haolebaoji waterworks has 22 production wells stretching northeast to southwest, which became operational for industrial purpose in 2006. The production wells were designed in the shape of rectangular grid at an interval of $1.5 \mathrm{~km}$ with each other. It is possible to operate individual wells separately and the production rate of individual wells was unknown. However, according to the data obtained by this study, the total production rate climbed from $12,932 \mathrm{~m}^{3} /$ day in 2006 to $24,746 \mathrm{~m}^{3} /$ day in 2012 with an average annual growth rate of $1969 \mathrm{~m}^{3} /$ day, and all the production wells are screened within the confined aquifer given high quality of confined groundwater.

The eight groundwater monitoring wells were well designed specially with well depths ranging from 6 to $300 \mathrm{~m}$. All sites were equipped 


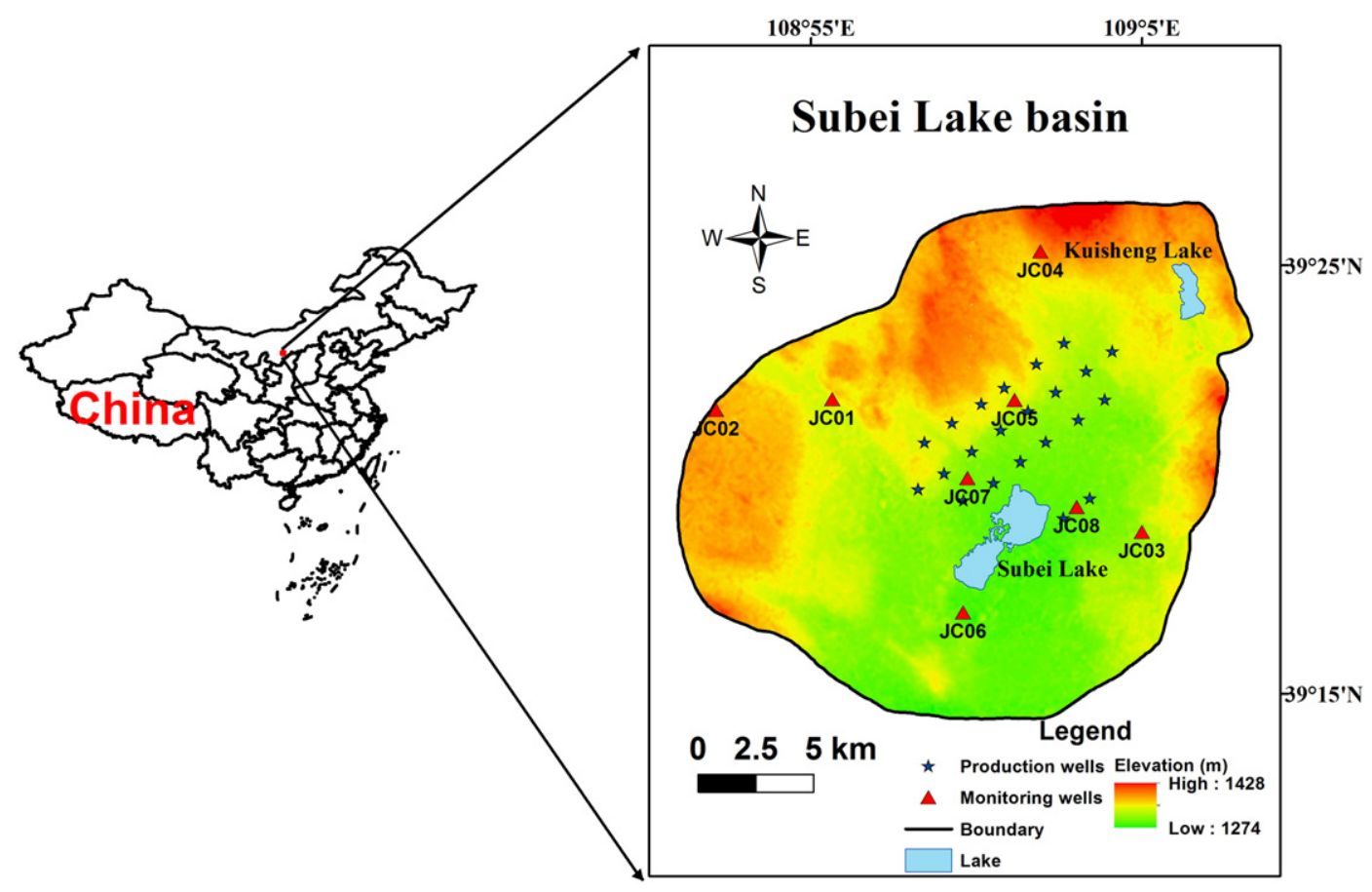

Fig. 1. Location map of the study area and spatial distribution of the production wells and the monitoring wells.

with data logger (KADEC-MIZU II, Japan) and the groundwater levels were recorded at 30-min intervals from the end of 2013 to December 2014. Given that confined aquifer was intensively exploited by 22 production wells, except for wells JC01 and JC06 which were used to monitor the unconfined aquifer, other six wells were used to monitor the confined aquifer (Fig. 1). The scope of groundwater depression cone was qualitatively identified by groundwater hydrographs, which may spread from the center area (wells JC05 and JC07) to the western boundary (well JC02). This is also in accordance with the results of groundwater flow model built by Wang et al. (2010). According to Wang et al. (2010), the downward leakage from the upper unconfined aquifer to confined aquifer will take place in most areas due to the intensive pumping from confined aquifer. Given the production wells are close to the Subei Lake, the groundwater that originally recharged the lake was extracted heavily for industrial usage. As a result, the intensive groundwater exploitation has caused the Subei Lake to shrink and groundwater-dependent vegetation degradation around the lake (Wang et al., 2010).

\subsection{Geologic and hydrogeologic setting}

The study area is controlled by the complex geologic conditions, which is represented by two distinct geologic units (i.e., the Quaternary unconsolidated sediments and Cretaceous strata). The Quaternary unconsolidated sediments are mainly distributed around the Subei Lake with relatively smaller thickness varying from 0 to $20 \mathrm{~m}$. The Quaternary layer is chiefly composed of the interlaced layers of sand and mud. The Cretaceous strata mainly consist of sedimentary sandstones and generally outcrop in the areas with relatively higher elevation. The maximum thickness of Cretaceous rocks could be nearly $1000 \mathrm{~m}$ in the Ordos Plateau (Yin et al., 2009). Calcite, dolomite, quartz, and feldspar are the major minerals in the Quaternary and Cretaceous strata. The sandstones are dominated mainly by quartz (30-50\%), Na and K feldspars (20-30\%), and calcite and dolomite (10\%). The evaporite minerals (halite and gypsum) also occur in the Quaternary sediments and Cretaceous sandstones, which were formed as a result of the drying up of enclosed lakes due to extremely arid environment (Hou et al., 2006; Yin et al., 2009).

The Subei Lake basin is a relatively closed hydrogeological unit given that a small quantity of lateral outflow occurs in a small part of southern boundary (Wang et al., 2010). Phreatic aquifer and confined aquifer can be observed in the investigated area. According to Wang et al. (2010), the unconfined aquifer is composed of the Quaternary sediments and the upper part of the Cretaceous strata, with its thickness ranging from 10.52 to $63.54 \mathrm{~m}$. The hydraulic conductivity of the aquifer ranges from 0.16 and $17.86 \mathrm{~m} /$ day. The specific yield of unconfined aquifer varies from 0.058 to 0.155 . The recharge of precipitation infiltration via vadose zone is the major source of unconfined groundwater; it can be also replenished by lateral inflow from groundwater outside the study area. In a natural state, upward leakage from the underlying confined aquifer and irrigation return flow can also contribute a small proportion to groundwater recharge. Evaporation is the major discharge pattern of the unconfined groundwater. In addition, unconfined groundwater is also discharged by lateral outflow, artificial exploitation and leakage discharge. Hydraulic head measurements conducted in the groundwater wells (in September 2003) were contoured to illustrate the general flow field in the area (Fig. 2a). As is shown in Fig. 2a, lateral outflow occurs in a small part of southern boundary by analyzing the contours and flow direction of groundwater. The groundwater flows predominantly from surrounding uplands to low lands, which is under the control of topography. Overall, groundwater in phreatic aquifer flows toward the Subei Lake and recharges lake water.

The unconfined and confined aquifers are separated by an uncontinuous aquitard composed of the mudstone layer, and discontinued mudstone lens also can be observed in Cretaceous strata. The lower part of Cretaceous strata can be viewed as confined or semi-confined in nature due to the presence of mudstone lens. The hydraulic properties of confined aquifer are variable in space. The hydraulic conductivity changes between 0.14 and $27.04 \mathrm{~m} /$ day, the hydraulic gradient varies from 0.0010 to 0.0045 and the storage coefficient ranges from $2.17 \times 10^{-5}$ to $1.98 \times 10^{-3}$ (Wang et al., 2010). The flow direction of confined groundwater was similar to that 

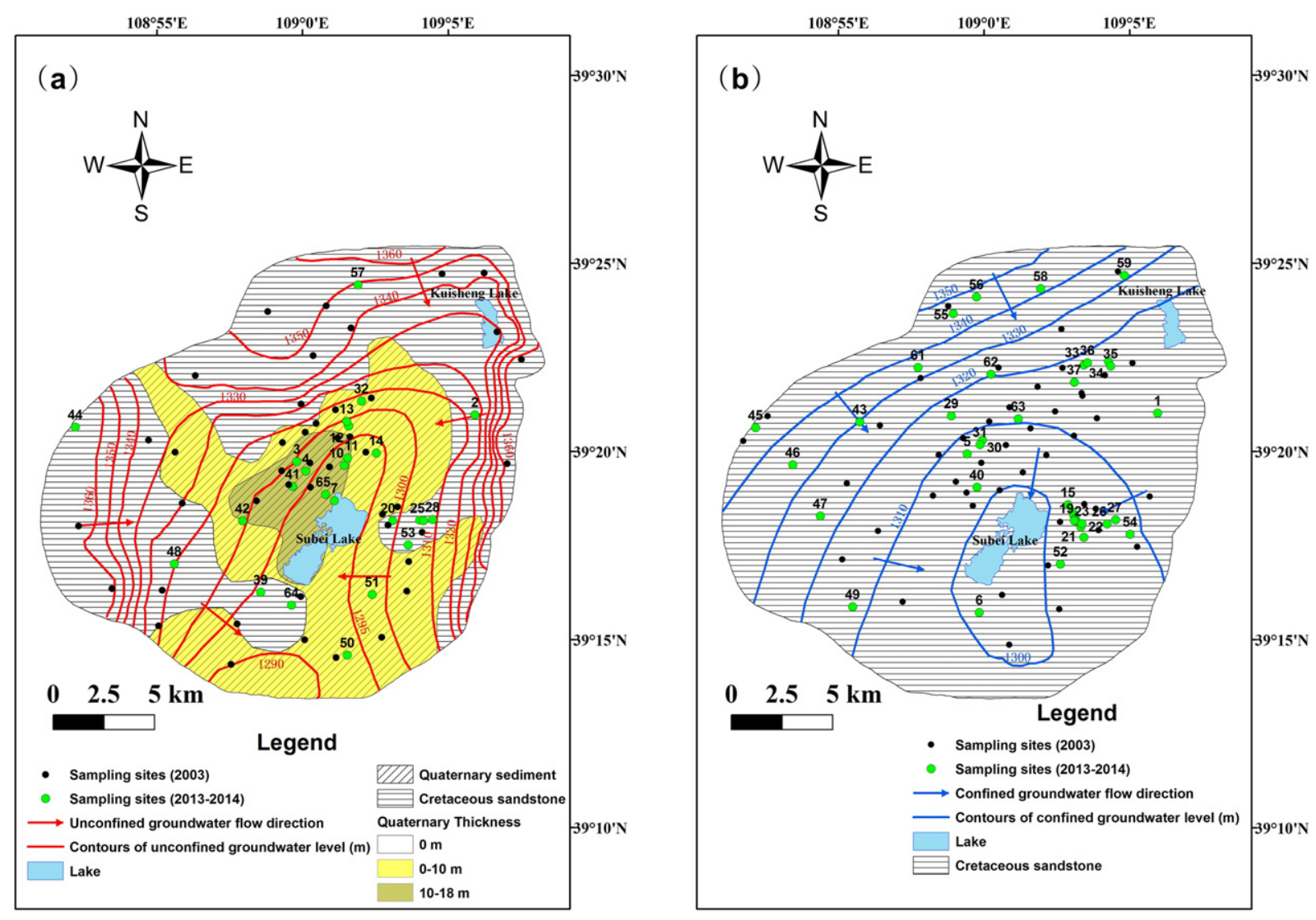

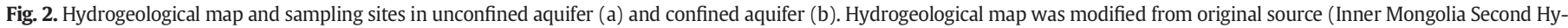
drogeology Engineering Geological Prospecting Institute, 2010).

of unconfined groundwater (Fig. 2b). Given the huge thickness and high permeability of confined aquifer, it is viewed as the most promising water-supply aquifer for domestic and industrial usages.

\section{Materials and methods}

\subsection{Sample collection and treatment}

In previous hydrogeological survey conducted by the Inner Mongolia Second Hydrogeology Engineering Prospecting Institute, a total of 159 groundwater samples had been collected during three sampling campaigns from March 2003 to September 2003 and the spatial distribution of hydrochemical types of groundwater in 2003 had been mapped.

In this study, a total of 153 groundwater samples were collected from 62 different sampling sites ( 25 sites for unconfined aquifer and 37 sites for confined aquifer) during three campaigns i.e., monsoon (August 2013), post-monsoon (December 2013) and pre-monsoon (May 2014). The sampling sites were shown in Fig. 2. The monitoring frequency was three times each well, but the occurrence of some unexpected events prevented the sampling in some wells. The groundwater samples were taken from wells for domestic and agricultural purposes ranging in depth from 2 to $300 \mathrm{~m}$ b.g.l. ( $\mathrm{m}$ below ground level). The diameter of the sampling wells ranges from 0.05 to $1.5 \mathrm{~m}$. The length of screen pipes made of stainless steel or PVC pipe in all sampling wells varies from 1 to $10 \mathrm{~m}$ and every sampling well has only one screen pipe rather than multiple screens. The distance between the bottom of screen pipe and the total well depth ranges from 0 to $3 \mathrm{~m}$ in the study area, the bottom depth of screen pipe was assigned to the water samples. The groundwater samples were mostly taken using pumps installed in these wells and groundwater was well purged for a few minutes at each site before sample collection. The $100 \mathrm{ml}$ and $50 \mathrm{ml}$ polyethylene bottles were pre-rinsed with water sample three times before the final water sample was collected. Celluose membrane filters $(0.45 \mu \mathrm{m})$ were used to filter samples for cations and anions analysis. All samples were sealed with adhesive tape and were stored in a portable cooler containing ice packs to prevent possible evaporation effects. Then, they were transported to the laboratory and refrigerated at $4{ }^{\circ} \mathrm{C}$ until analysis. The global positioning system (GPS) was applied to locate the geographic coordinates of each sampling site.

\subsection{Analytical techniques}

Before sampling, some physico-chemical parameters of the groundwater were measured on-site. Electrical conductivity (EC), $\mathrm{pH}$ value and water temperature of each sample were measured in situ using an $\mathrm{EC} / \mathrm{pH}$ meter (WM-22EP, DKK-TOA, Japan), and dissolved oxygen (DO) and oxidation-reduction potential (ORP) were also determined using a $\mathrm{HACH}$ HQ30d Single-Input Multi-Parameter Digital Meter. All the probes were calibrated using appropriate standard solutions or procedures before sampling of the groundwater. In situ these hydrochemical parameters were monitored until these values reached a steady state.

The major hydrochemical parameters were analyzed at the Center for Physical and Chemical Analysis of Institute of Geographic Sciences and Natural Resources Research, Chinese Academy of Sciences (IGSNRR, CAS). Major ion compositions were measured for each sample, $\mathrm{K}^{+}, \mathrm{Na}^{+}$, $\mathrm{Ca}^{2+}, \mathrm{Mg}^{2+}, \mathrm{Cl}^{-}, \mathrm{SO}_{4}^{2-}$ and $\mathrm{NO}_{3}^{-}$included. An inductively coupled plasma optical emission spectrometer (ICP-OES) (Perkin-Elmer Optima 5300DV, USA) was applied to analyze major cations. Major anions were measured on ion chromatography (ICS-2100, Dionex, USA). The total alkalinity $\left(\right.$ as $\mathrm{HCO}_{3}^{-}$) in all groundwater samples was determined by the titration method on the day of sampling, methyl orange endpoint titration was adopted with the final $\mathrm{pH}$ being $4.2-4.4$. The reliability of the hydrochemical data was assessed by checking ion balances. 
Calculated charge balance errors were found to be less than $\pm 10 \%$ which is an acceptable uncertainty for the purpose of this study.

In order to elucidate the hydrochemical characteristic in groundwater, the interpretation of the water quality data was based on the use of statistical parameters such as maximum, minimum, mean, standard deviation (Carucci et al., 2012; Huang et al., 2013; Wang et al., 2014). In addition, the comparison between hydrochemical data before the operation of Haolebaoji waterworks (BO) (2003) and that at the present stage of the operation of Haolebaoji waterworks (PO) (2013-2014) was conducted in order to assess the anthropogenic factors affecting groundwater chemistry. Here, hydrochemical data in BO is quoted from the regional hydrogeological survey report from Inner Mongolia Second Hydrogeology Engineering Geological Prospecting Institute.

\section{Results}

\subsection{General hydrochemistry}

\subsubsection{Hydrochemical characteristic of unconfined aquifer}

The EC values of unconfined groundwater for monsoon, postmonsoon and pre-monsoon varied from 435 to 1818,433 to 2010, and 450 to $1786 \mu \mathrm{S} / \mathrm{cm}$ with averages 915,931 and $811 \mu \mathrm{S} / \mathrm{cm}$, respectively. The $\mathrm{pH}$ values for monsoon, post-monsoon and pre-monsoon ranged from 7.4 to $9.0,7.5$ to 9.3 , and 7.8 to 9.4 with averages $7.9,8.1,8.3$, respectively (Table 1 ). It indicates an alkaline nature during the three campaigns. Overall, water temperature varied from 5.1 to $18.1{ }^{\circ} \mathrm{C}$ with an average value of $10.9{ }^{\circ} \mathrm{C}$ and the order of the mean water temperature was Monsoon (mean value: $13.5^{\circ} \mathrm{C}$ ) > Pre-monsoon (mean value: $10.9{ }^{\circ} \mathrm{C}$ ) > Post-monsoon (mean value: $9.3^{\circ} \mathrm{C}$ ). The DO and ORP ranged from 0.99 to $9.50 \mathrm{mg} / \mathrm{L}$ and from -111.1 to $140.6 \mathrm{mV}$, respectively, and the seasonal change of DO was in accordance with that of ORP. The ionic composition was dominated by $\mathrm{Na}^{+}$(13.2$267.2 \mathrm{mg} / \mathrm{L}), \mathrm{Ca}^{2+}$ (7.7-181.9 mg/L), $\mathrm{HCO}_{3}^{-}$(130.8-457.1 mg/L), $\mathrm{SO}_{4}^{2-}$ $(12.8-700.1 \mathrm{mg} / \mathrm{L})$. By contrast, concentrations of $\mathrm{Mg}^{2+}(13.2-$ $111.4 \mathrm{mg} / \mathrm{L}), \mathrm{K}^{+}(0.9-9.0 \mathrm{mg} / \mathrm{L})$, and $\mathrm{Cl}^{-}(8.0-233.3 \mathrm{mg} / \mathrm{L})$ were relatively lower. Irrespective of seasonal variations, the general order of abundance of major cations was $\mathrm{Na}^{+}>\mathrm{Ca}^{2+}>\mathrm{Mg}^{2+}>\mathrm{K}^{+}$, while the abundance of major anions was that $\mathrm{HCO}_{3}^{-}$far exceeded $\mathrm{SO}_{4}^{2-}$ and $\mathrm{Cl}^{-}$ . It can be clearly observed that the concentrations of major cations did not undergo an appreciable change during the three campaigns, while the concentrations of major anions were highest during the monsoon (Fig. 3a). The concentration of $\mathrm{NO}_{3}^{-}$varied from 0.6 to $147.4 \mathrm{mg} / \mathrm{L}$ with an average of $27.9 \mathrm{mg} / \mathrm{L}$, and the seasonal change of the nitrate concentration was Post-monsoon (mean value: $29.9 \mathrm{mg} / \mathrm{L}$ ) > Premonsoon (mean value: $27.5 \mathrm{mg} / \mathrm{L}$ ) > Monsoon (mean value: $25.2 \mathrm{mg} / \mathrm{L}$ ).

A bivariate correlation analysis is applied to describe the relationship between two hydrochemical parameters (Table 2). The result of the correlation analysis is discussed in the subsequent interpretation. All of the major cations and anions except $\mathrm{HCO}_{3}^{-}$and $\mathrm{NO}_{3}^{-}$are significantly correlated with EC, which shows that these ions have been released into groundwater continuously due to the predominance of water-rock interaction, and then resulted in the rise of EC. As is shown in Table 2, the concentration of $\mathrm{Na}^{+}$is correlated with $\mathrm{Cl}^{-}$and $\mathrm{SO}_{4}^{2-}$, with significantly positive correlation coefficients of 0.87 and 0.51 , respectively. The concentration of $\mathrm{Ca}^{2+}$ is well correlated with $\mathrm{SO}_{4}^{2-}$ with a correlation coefficient of 0.63 .

\subsubsection{Hydrochemical characteristic of confined aquifer}

The EC values of confined groundwater for monsoon, post-monsoon and pre-monsoon ranged from 470 to 2330,419 to 2470, and 392 to $2124 \mu \mathrm{S} / \mathrm{cm}$ with averages 800,692 and $674 \mu \mathrm{S} / \mathrm{cm}$, respectively. The $\mathrm{pH}$ values for monsoon, post-monsoon and pre-monsoon ranged from 7.4 to $8.3,7.5$ to 9.4 , and 7.7 to 9.1 with averages $7.8,8.2,8.3$, respectively (Table 3). On the whole, water temperature varied from 6.4 to $24.4^{\circ} \mathrm{C}$ with an average value of $11.1^{\circ} \mathrm{C}$ and the seasonal variation was similar to that of the temperature of unconfined groundwater, which may be attributed to the strong mixture between them. The DO and ORP ranged from 1.83 to $10.83 \mathrm{mg} / \mathrm{L}$ and from -13.9 to $139.3 \mathrm{mV}$, respectively. The ionic composition is dominated by $\mathrm{Ca}^{2+}(2.1-192.8 \mathrm{mg} / \mathrm{L}), \mathrm{Na}^{+}$ (16.1-211.3 mg/L), $\mathrm{HCO}_{3}^{-}$(158.6-1044.3 mg/L). By contrast, concentrations of $\mathrm{Mg}^{2+}(1.2-99.6 \mathrm{mg} / \mathrm{L}), \mathrm{K}^{+}(1.0-7.6 \mathrm{mg} / \mathrm{L}), \mathrm{Cl}^{-}$ $(5.1-214.6 \mathrm{mg} / \mathrm{L}), \mathrm{SO}_{4}^{2-}(1.4-241.5 \mathrm{mg} / \mathrm{L})$ and $\mathrm{NO}_{3}^{-}(0.8-385.3 \mathrm{mg} / \mathrm{L})$ were relatively lower. The order of abundance of major cations was $\mathrm{Na}^{+-}$ $>\mathrm{Ca}^{2+}>\mathrm{Mg}^{2+}>\mathrm{K}^{+}$, while the abundance of major anions was $\mathrm{HCO}_{3}^{-}$ $>\mathrm{Cl}^{-}>\mathrm{SO}_{4}^{2-}$. The order of abundance of major elements (except $\mathrm{K}^{+}$ and $\mathrm{HCO}_{3}^{-}$) was Monsoon > Pre-monsoon > Post-monsoon. There was almost no change in the concentrations of potassium, but the order of the concentrations of bicarbonate was Monsoon (mean value: $287.9 \mathrm{mg} / \mathrm{L}$ ) > Post-monsoon (mean value: $248.6 \mathrm{mg} / \mathrm{L}$ ) > Premonsoon (mean value: $233.8 \mathrm{mg} / \mathrm{L}$ ) (Fig. 3b). The concentration of $\mathrm{NO}_{3}^{-}$ranged from 0.8 to $385.3 \mathrm{mg} / \mathrm{L}$ with an average of $58.7 \mathrm{mg} / \mathrm{L}$, and the seasonal change of the nitrate concentration was Monsoon (mean value: $85.8 \mathrm{mg} / \mathrm{L}$ ) > Pre-monsoon (mean value: $55.9 \mathrm{mg} / \mathrm{L}$ ) > Postmonsoon (mean value: $45.7 \mathrm{mg} / \mathrm{L}$ ).

Table 1

Statistical summary of hydrochemical parameters of unconfined groundwater.

\begin{tabular}{|c|c|c|c|c|c|c|c|c|c|c|c|c|c|c|}
\hline & $\begin{array}{l}\mathrm{EC} \\
(\mu \mathrm{S} / \mathrm{cm})\end{array}$ & $\begin{array}{l}\mathrm{T} \\
\left({ }^{\circ} \mathrm{C}\right)\end{array}$ & $\mathrm{pH}$ & $\begin{array}{l}\text { DO } \\
(\mathrm{mg} / \mathrm{L})\end{array}$ & $\begin{array}{l}\text { ORP } \\
(\mathrm{mV})\end{array}$ & $\begin{array}{l}\mathrm{K}^{+} \\
(\mathrm{mg} / \mathrm{L})\end{array}$ & $\begin{array}{l}\mathrm{Na}^{+} \\
(\mathrm{mg} / \mathrm{L})\end{array}$ & $\begin{array}{l}\mathrm{Ca}^{2+} \\
(\mathrm{mg} / \mathrm{L})\end{array}$ & $\begin{array}{l}\mathrm{Mg}^{2+} \\
(\mathrm{mg} / \mathrm{L})\end{array}$ & $\begin{array}{l}\mathrm{Cl}^{-} \\
(\mathrm{mg} / \mathrm{L})\end{array}$ & $\begin{array}{l}\mathrm{SO}_{4}^{2-} \\
(\mathrm{mg} / \mathrm{L})\end{array}$ & $\begin{array}{l}\mathrm{HCO}_{3}^{-} \\
(\mathrm{mg} / \mathrm{L})\end{array}$ & $\begin{array}{l}\mathrm{NO}_{3}^{-} \\
(\mathrm{mg} / \mathrm{L})\end{array}$ & $\begin{array}{l}\text { TDS } \\
(\mathrm{mg} / \mathrm{L})\end{array}$ \\
\hline \multicolumn{15}{|c|}{ Total $(n=59)$} \\
\hline Min & 433 & 5.1 & 7.4 & 0.99 & -111.1 & 0.9 & 13.2 & 7.7 & 13.2 & 8.0 & 12.8 & 130.8 & 0.6 & 217.4 \\
\hline Max & 2010 & 18.1 & 9.4 & 9.50 & 140.6 & 9.0 & 267.2 & 181.9 & 111.4 & 233.3 & 700.1 & 457.1 & 147.4 & 1201.9 \\
\hline Mean & 885 & 10.9 & 8.1 & 4.70 & 19.4 & 3.4 & 71.1 & 64.1 & 35.4 & 42.7 & 111.7 & 271.1 & 27.9 & 491.9 \\
\hline Std & 406 & 2.5 & 0.4 & 2.34 & 58.6 & 1.6 & 51.4 & 34.4 & 23.3 & 44.0 & 148.1 & 66.3 & 35.9 & 239.7 \\
\hline \multicolumn{15}{|c|}{ Monsoon $(n=14)$} \\
\hline Min & 435 & 10.8 & 7.4 & 1.80 & -111.1 & 0.9 & 14.1 & 11.0 & 14.4 & 9.6 & 14.9 & 158.6 & 1.0 & 249.4 \\
\hline Max & 1818 & 18.1 & 9.0 & 8.61 & 103.8 & 9.0 & 227.5 & 178.7 & 93.9 & 216.6 & 700.1 & 442.9 & 129.8 & 1201.9 \\
\hline Mean & 915 & 13.5 & 7.9 & 4.28 & 12.1 & 3.7 & 72.8 & 63.3 & 37.0 & 54.5 & 132.6 & 286.4 & 25.2 & 532.2 \\
\hline Std & 424 & 2.3 & 0.4 & 2.22 & 63.9 & 1.8 & 53.7 & 41.2 & 22.3 & 53.3 & 177.8 & 69.9 & 33.9 & 269.6 \\
\hline \multicolumn{15}{|c|}{ Post-monsoon $(n=24)$} \\
\hline Min & 433 & 5.1 & 7.5 & 1.66 & -85.7 & 1.3 & 13.2 & 13.0 & 13.2 & 8.0 & 12.8 & 130.8 & 0.9 & 217.4 \\
\hline Max & 2010 & 11.1 & 9.3 & 9.50 & 93.8 & 7.4 & 226.0 & 181.9 & 111.4 & 172.7 & 604.3 & 457.1 & 147.4 & 1107.9 \\
\hline Mean & 931 & 9.3 & 8.1 & 5.25 & 14.7 & 3.5 & 63.9 & 67.4 & 36.3 & 33.2 & 109.2 & 274.5 & 29.9 & 480.6 \\
\hline Std & 442 & 1.5 & 0.3 & 2.39 & 52.0 & 1.4 & 44.8 & 36.8 & 26.3 & 33.5 & 157.2 & 69.0 & 40.5 & 240.6 \\
\hline \multicolumn{15}{|c|}{ Pre-monsoon $(n=21)$} \\
\hline Min & 450 & 7.2 & 7.8 & 0.99 & -73.5 & 1.7 & 20.7 & 7.7 & 14.2 & 9.6 & 17.3 & 137.3 & 0.6 & 257.4 \\
\hline Max & 1786 & 15.3 & 9.4 & 8.38 & 140.6 & 8.3 & 267.2 & 121.6 & 95.5 & 233.3 & 513.3 & 424.1 & 120.2 & 1076.1 \\
\hline Mean & 811 & 10.9 & 8.3 & 4.35 & 29.7 & 3.2 & 78.3 & 60.9 & 33.5 & 45.7 & 100.5 & 257.1 & 27.5 & 478.1 \\
\hline Std & 357 & 2.1 & 0.4 & 2.35 & 63.5 & 1.7 & 58.0 & 27.2 & 21.2 & 47.6 & 119.2 & 60.8 & 33.0 & 226.6 \\
\hline
\end{tabular}




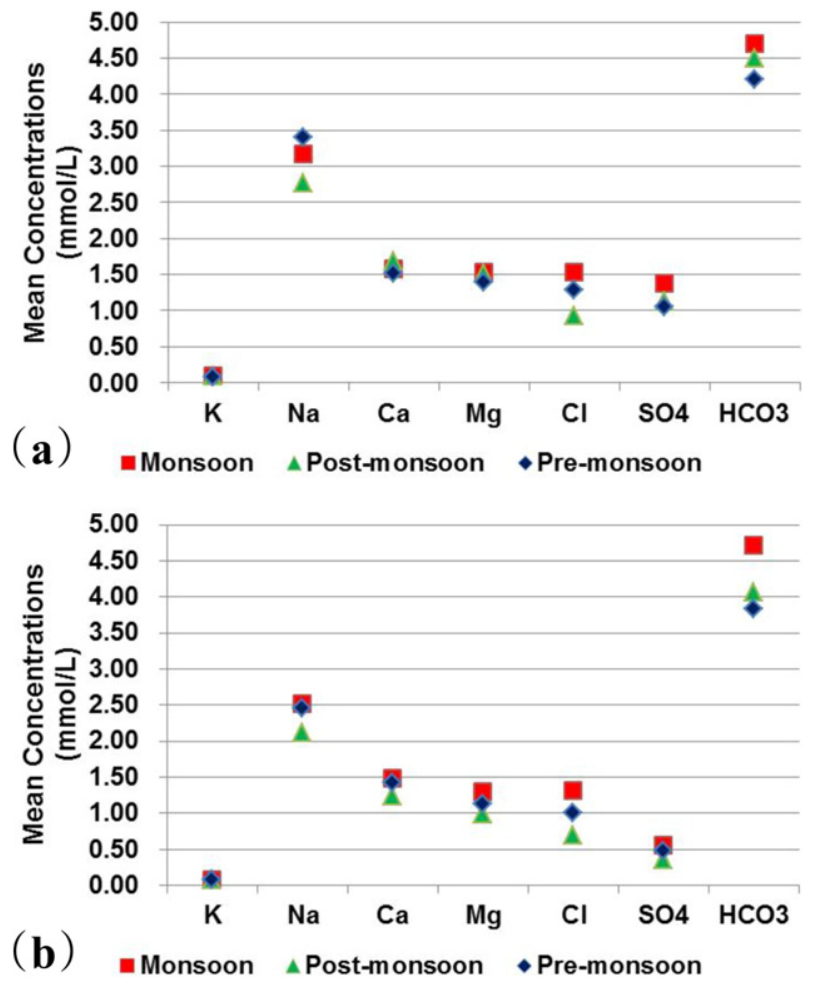

Fig. 3. Seasonal variation of the major chemical constituents in the phreatic aquifer (a) and the confined aquifer (b).

Correlation analysis was also applied to the hydrochemical parameters of confined groundwater (Table 4). EC is positively correlated with major ions, which reflects that water-rock interaction is mainly responsible for the groundwater mineralization. $\mathrm{Na}^{+}$shows good correlations with $\mathrm{HCO}_{3}^{-}, \mathrm{Cl}^{-}$and $\mathrm{SO}_{4}^{2-}$, with correlation coefficients of $0.77,0.79$ and 0.72 , respectively. The concentration of $\mathrm{Ca}^{2+}$ is well correlated with $\mathrm{SO}_{4}^{2-}$ with a correlation coefficient of 0.79 . Bicarbonate has good correlations with $\mathrm{Ca}^{2+}$ and $\mathrm{Mg}^{2+}$, with significantly positive correlation coefficients of 0.60 and 0.83 . In addition, surprisingly, the concentration of $\mathrm{NO}_{3}^{-}$is significantly correlated with $\mathrm{Ca}^{2+}$ and $\mathrm{SO}_{4}^{2-}$, with correlation coefficients of 0.68 and 0.59 , respectively.

\subsection{Hydrochemical facies}

The geochemical evolution of groundwater can be identified by plotting the concentrations of major cations and anions in the Piper tri-linear diagram (Piper, 1953). Fig. 4a shows the results of plotting the 59 unconfined groundwater samples on the Piper diagram. With respect to cations, all the points are distributed in zones $A, B$ and D of the lower-left triangle, indicating that some are calcium-type, some are sodium-type water but a mixed type predominates. Concerning anions, $85 \%$ of groundwater samples are lumped in zone E of the lowerright triangle, the rest of the samples are sulfate type and no dominant type (Fig. 4a), so bicarbonate-type water is predominant. The important information that can discriminate between separate groups of samples can be derived from the central diamond plot. It is clearly that almost $81 \%$ samples are scattered in zone 5, indicating that the alkaline earths and the bicarbonate are the most common in groundwater chemistry of phreatic aquifer in the study area. It also validates the relatively small seasonal variation of chemical constituents in most samples. It should be noted that three samples from well 14 during three campaigns are scattered in zone 7 , showing that alkalics and strong acids predominate. The samples from well 03 exhibit a typical mixed type of groundwater chemistry irrespective of seasonal change. However, a mixed water type (M11) was only observed in well 11 during the premonsoon. It is worth noted that the hydrochemical type in well 04 during the monsoon and post-monsoon ( $\mathrm{A04}$, D04) was $\mathrm{Ca}-\mathrm{Mg}-\mathrm{SO}_{4}$ type, however, the chemical composition in groundwater during the premonsoon ( $\mathrm{M0} 4$ in zone 9) changed to $\mathrm{Na}-\mathrm{HCO}_{3}$ type. The obvious shift of hydrochemical facies in some samples can be explained by the ion exchange and the increasingly closely hydraulic connections between the unconfined and the confined aquifers. For examples, given that well 11 is surrounded by the production wells of Haolebaoji waterworks, the strong mixture may result in a mixed water type (M11) due to the interference from intensive groundwater pumping. Similarly, the significant changes in hydrochemical facies for well 04 and other sampling wells may also be interpreted as a result of the strong interference from intensive groundwater pumping. Only one sample was collected from well 07 (A07 in zone 9) during monsoon and its hydrochemical pattern was $\mathrm{Na}-\mathrm{HCO}_{3}$ type. Therefore, the hydrochemical facies in unconfined groundwater can be classified into a variety of water types including $\mathrm{Ca}-\mathrm{Mg}-\mathrm{HCO}_{3}, \mathrm{Ca}-\mathrm{Na}-\mathrm{HCO}_{3}, \mathrm{Na}-\mathrm{Ca}-\mathrm{HCO}_{3}, \mathrm{Na}-\mathrm{HCO}_{3}, \mathrm{Ca}-\mathrm{Mg}-$ $\mathrm{SO}_{4}$ and $\mathrm{Na}-\mathrm{SO}_{4}-\mathrm{Cl}$ types.

Fig. $4 \mathrm{~b}$ shows the results of plotting the 94 confined groundwater samples on the Piper diagram. The distributed characteristic of the major cations in the confined groundwater is similar to that of unconfined groundwater. Regarding anions, almost 96\% of groundwater samples are distributed in zone $\mathrm{E}$ of the lower-right triangle, no dominant type is only observed in four samples (Fig. 4b), so bicarbonate is the most common anion in confined aquifer. It should be noted that almost $79 \%$ of the 94 groundwater samples are scattered in zone 5, indicating that the chemical elements of groundwater in confined aquifer are mainly composed of the alkaline earths and the bicarbonate. Nearly $19 \%$ of all the samples are scattered in zone 9, showing that the hydrochemical characteristics of these samples are the consequence of the strong mixture among different sources of water. The samples from well 40 are scattered in zone 8 , indicating that alkalics and weak

Table 2

Pearson correlation coefficients of major hydrochemical parameters in unconfined groundwater.

\begin{tabular}{|c|c|c|c|c|c|c|c|c|c|c|}
\hline & $E C^{\mathrm{a}}$ & $\mathrm{pH}$ & $\mathrm{K}^{+}$ & $\mathrm{Na}^{+}$ & $\mathrm{Ca}^{2+}$ & $\mathrm{Mg}^{2+}$ & $\mathrm{Cl}^{-}$ & $\mathrm{SO}_{4}^{2-}$ & $\mathrm{HCO}_{3}^{-}$ & $\mathrm{NO}_{3}^{-}$ \\
\hline $\mathrm{EC}^{\mathrm{a}}$ & 1.00 & & & & & & & & & \\
\hline $\mathrm{pH}$ & 0.07 & 1.00 & & & & & & & & \\
\hline $\mathrm{K}^{+}$ & $0.55^{* *}$ & 0.15 & 1.00 & & & & & & & \\
\hline $\mathrm{Na}^{+}$ & $0.74^{* *}$ & $0.45^{* *}$ & $0.62^{* *}$ & 1.00 & & & & & & \\
\hline $\mathrm{Ca}^{2+}$ & $0.46^{* *}$ & $-0.48^{* *}$ & -0.09 & -0.17 & 1.00 & & & & & \\
\hline $\mathrm{Mg}^{2+}$ & $0.94^{* *}$ & -0.04 & $0.52^{* *}$ & $0.58^{* *}$ & $0.54^{* *}$ & 1.00 & & & & \\
\hline $\mathrm{Cl}^{-}$ & $0.65^{* *}$ & $0.48^{* *}$ & $0.62^{* *}$ & $0.87^{* *}$ & -0.24 & $0.52^{* *}$ & 1.00 & & & \\
\hline $\mathrm{SO}_{4}^{2-}$ & $0.88^{* *}$ & -0.03 & $0.28^{*}$ & $0.51^{* *}$ & $0.63^{* *}$ & $0.90^{* *}$ & $0.36^{* *}$ & 1.00 & & \\
\hline $\mathrm{HCO}_{3}^{-}$ & $0.27^{*}$ & $-0.34^{* *}$ & $0.47^{* *}$ & $0.26^{*}$ & 0.17 & 0.22 & 0.18 & 0.01 & 1.00 & \\
\hline $\mathrm{NO}_{3}^{-}$ & $-0.28^{*}$ & -0.07 & -0.21 & $-0.40^{* *}$ & 0.09 & $-0.28^{*}$ & -0.24 & $-0.35^{* *}$ & -0.22 & 1.00 \\
\hline
\end{tabular}

All concentrations (except as noted) are in $\mathrm{mg} / \mathrm{L}$. $\mathrm{pH}$ is in standard units.

a Electrical conductivity $(\mu \mathrm{S} / \mathrm{cm})$.

** Correlation is significant at the 0.01 level (2-tailed).

* Correlation is significant at the 0.05 level (2-tailed). 
Table 3

Statistical summary of hydrochemical parameters of confined groundwater.

\begin{tabular}{|c|c|c|c|c|c|c|c|c|c|c|c|c|c|c|}
\hline & $\begin{array}{l}\mathrm{EC} \\
(\mu \mathrm{S} / \mathrm{cm})\end{array}$ & $\begin{array}{l}\mathrm{T} \\
\left({ }^{\circ} \mathrm{C}\right)\end{array}$ & $\mathrm{pH}$ & $\begin{array}{l}\text { DO } \\
(\mathrm{mg} / \mathrm{L})\end{array}$ & $\begin{array}{l}\text { ORP } \\
(\mathrm{mV})\end{array}$ & $\begin{array}{l}\mathrm{K}^{+} \\
(\mathrm{mg} / \mathrm{L})\end{array}$ & $\begin{array}{l}\mathrm{Na}^{+} \\
(\mathrm{mg} / \mathrm{L})\end{array}$ & $\begin{array}{l}\mathrm{Ca}^{2+} \\
(\mathrm{mg} / \mathrm{L})\end{array}$ & $\begin{array}{l}\mathrm{Mg}^{2+} \\
(\mathrm{mg} / \mathrm{L})\end{array}$ & $\begin{array}{l}\mathrm{Cl}^{-} \\
(\mathrm{mg} / \mathrm{L})\end{array}$ & $\begin{array}{l}\mathrm{SO}_{4}^{2-} \\
(\mathrm{mg} / \mathrm{L})\end{array}$ & $\begin{array}{l}\mathrm{HCO}_{3}^{-} \\
(\mathrm{mg} / \mathrm{L})\end{array}$ & $\begin{array}{l}\mathrm{NO}_{3}^{-} \\
(\mathrm{mg} / \mathrm{L})\end{array}$ & $\begin{array}{l}\text { TDS } \\
(\mathrm{mg} / \mathrm{L})\end{array}$ \\
\hline \multicolumn{15}{|c|}{ Total $(n=94)$} \\
\hline Min & 392 & 6.4 & 7.4 & 1.83 & -13.9 & 1.0 & 16.1 & 2.1 & 1.2 & 5.1 & 1.4 & 158.6 & 0.8 & 215.2 \\
\hline Max & 2470 & 24.4 & 9.4 & 10.83 & 139.3 & 7.6 & 211.3 & 192.8 & 99.6 & 214.6 & 241.5 & 1044.3 & 385.3 & 1424.2 \\
\hline Mean & 709 & 11.1 & 8.1 & 6.52 & 61.4 & 2.9 & 53.9 & 54.8 & 26.8 & 33.9 & 43.2 & 251.6 & 58.7 & 399.9 \\
\hline Std & 404 & 2.5 & 0.4 & 2.37 & 30.4 & 1.3 & 40.6 & 33.7 & 17.4 & 38.9 & 41.0 & 133.7 & 65.4 & 244.3 \\
\hline \multicolumn{15}{|c|}{ Monsoon $(n=21)$} \\
\hline Min & 470 & 10.9 & 7.4 & 1.96 & 20.0 & 1.0 & 27.1 & 14.1 & 14.7 & 10.8 & 15.8 & 158.6 & 1.2 & 266.4 \\
\hline Max & 2330 & 18.9 & 8.3 & 7.99 & 88.9 & 7.6 & 203.5 & 171.8 & 99.6 & 214.6 & 229.5 & 1044.3 & 374.6 & 1383.0 \\
\hline Mean & 800 & 12.8 & 7.8 & 6.06 & 56.3 & 2.9 & 58.0 & 59.3 & 31.1 & 46.8 & 54.2 & 287.9 & 85.8 & 482.0 \\
\hline Std & 496 & 2.0 & 0.2 & 2.02 & 20.6 & 1.4 & 41.1 & 38.5 & 21.0 & 53.6 & 49.7 & 180.5 & 95.5 & 315.7 \\
\hline \multicolumn{15}{|c|}{ Post-monsoon $(n=36)$} \\
\hline Min & 419 & 6.4 & 7.5 & 2.48 & -13.9 & 1.4 & 16.1 & 2.1 & 1.2 & 5.1 & 2.0 & 176.4 & 1.0 & 215.2 \\
\hline Max & 2470 & 14.2 & 9.4 & 10.83 & 107.7 & 7.3 & 206.4 & 146.5 & 99.0 & 134.9 & 147.8 & 967.2 & 235.4 & 1239.5 \\
\hline Mean & 692 & 9.5 & 8.2 & 6.73 & 56.2 & 2.9 & 48.7 & 49.8 & 23.9 & 24.6 & 33.9 & 248.6 & 45.7 & 353.8 \\
\hline Std & 392 & 1.4 & 0.3 & 2.51 & 24.6 & 1.3 & 38.0 & 29.7 & 15.9 & 27.8 & 31.9 & 128.9 & 40.0 & 199.3 \\
\hline \multicolumn{15}{|c|}{ Pre-monsoon $(n=37)$} \\
\hline Min & 392 & 7.9 & 7.7 & 1.83 & -1.4 & 1.3 & 20.3 & 6.9 & 5.4 & 6.7 & 1.4 & 179.8 & 0.8 & 218.8 \\
\hline Max & 2124 & 24.4 & 9.1 & 10.73 & 139.3 & 6.2 & 211.3 & 192.8 & 93.8 & 185.8 & 241.5 & 800.2 & 385.3 & 1424.2 \\
\hline Mean & 674 & 11.6 & 8.3 & 6.57 & 69.3 & 2.9 & 56.5 & 57.2 & 27.2 & 35.5 & 46.0 & 233.8 & 55.9 & 398.2 \\
\hline Std & 361 & 2.8 & 0.4 & 2.45 & 38.2 & 1.2 & 43.2 & 34.7 & 16.4 & 37.1 & 42.5 & 103.9 & 61.9 & 232.6 \\
\hline
\end{tabular}

acids predominate. Therefore, the main hydrochemical facies in confined groundwater are $\mathrm{Ca}-\mathrm{Mg}-\mathrm{HCO}_{3}, \mathrm{Ca}-\mathrm{Na}-\mathrm{HCO}_{3}, \mathrm{Na}-\mathrm{Ca}-\mathrm{HCO}_{3}$, $\mathrm{Ca}-\mathrm{HCO}_{3}$ and $\mathrm{Na}-\mathrm{HCO}_{3}$ types.

\section{Discussion}

\subsection{Natural factors affecting groundwater chemistry}

\subsubsection{Geochemical processes}

As discussed in the previous section, $\mathrm{Na}^{+}$shows a good correlation with $\mathrm{Cl}^{-}$for unconfined aquifer $\left(\mathrm{R}^{2}=0.87\right)$ and confined aquifer $\left(R^{2}=0.79\right)$, indicating the dissolution of halite is the major geochemical process in groundwater system as shown in the reaction (R1). There is a good correlation between $\mathrm{Na}^{+}$and $\mathrm{SO}_{4}^{2-}$ in the phreatic aquifer $\left(R^{2}=0.51\right)$ and confined aquifer $\left(R^{2}=0.72\right)$, suggesting that the dissolution of Glauber's salt $\left(\mathrm{Na}_{2} \mathrm{SO}_{4} \cdot 10 \mathrm{H}_{2} \mathrm{O}\right)$ may be the major sources of such ions in groundwater by the reaction (R2). The same situation can be observed in the Habor Lake basin (Yin et al., 2009). $\mathrm{Ca}^{2+}$ has a good correlation with $\mathrm{SO}_{4}^{2-}$ regardless of unconfined aquifer $\left(\mathrm{R}^{2}=\right.$ 0.63 ) or confined aquifer $\left(R^{2}=0.79\right)$, implying that the dissolution of gypsum may be one of the key factors controlling the geochemical evolution of groundwater, which can be explained by reaction (R3). Just as the achievements obtained by Hou et al. (2006), gypsum is common in these strata, so it is reasonable to consider that gypsum is the main source of the $\mathrm{SO}_{4}^{2-}$. $\mathrm{HCO}_{3}^{-}$is well correlated with $\mathrm{Ca}^{2+}\left(\mathrm{R}^{2}=0.60\right)$ or
$\mathrm{Mg}^{2+}\left(\mathrm{R}^{2}=0.83\right)$ in confined aquifer, indicating that the weathering of carbonate minerals (calcite and dolomite) contributes such ions to the groundwater, as expressed in reactions (R4, R5). The same happens in the Habor Lake basin of Ordos plateau (Yin et al., 2009). However, there is no good correlation between $\mathrm{HCO}_{3}^{-}$and $\mathrm{Ca}^{2+}\left(\mathrm{R}^{2}=0.17\right)$ or $\mathrm{Mg}^{2+}\left(\mathrm{R}^{2}=0.22\right)$ in the phreatic aquifer, it is reasonable to regard the dissolution of carbonate minerals as a source of $\mathrm{Ca}^{2+}, \mathrm{Mg}^{2+}$ and $\mathrm{HCO}_{3}^{-}$due to widespread occurrence of carbonate rocks. The dissolution of carbonate minerals was very likely to take place in the first phases of the geochemical evolution in unconfined aquifer and the equilibrium state was reached quickly, followed by cation exchange. $\mathrm{Mg}^{2+}$ is well correlated with $\mathrm{SO}_{4}^{2-}$ in unconfined aquifer $\left(\mathrm{R}^{2}=0.90\right)$ and confined aquifer $\left(R^{2}=0.84\right)$, suggesting the possible dissolution of gypsum, followed by cation exchange.

$$
\mathrm{NaCl} \rightarrow \mathrm{Na}^{+}+\mathrm{Cl}^{-}
$$

$\mathrm{Na}_{2} \mathrm{SO}_{4} \cdot 10 \mathrm{H}_{2} \mathrm{O} \rightarrow 2 \mathrm{Na}^{+}+\mathrm{SO}_{4}{ }^{2-}+10 \mathrm{H}_{2} \mathrm{O}$

$\mathrm{CaSO}_{4} \Leftrightarrow \mathrm{Ca}^{2+}+\mathrm{SO}_{4}^{2-}$

$\mathrm{CaCO}_{3}+\mathrm{CO}_{2}+\mathrm{H}_{2} \mathrm{O} \Leftrightarrow \mathrm{Ca}^{2+}+2 \mathrm{HCO}_{3}{ }^{-}$

$\mathrm{CaMg}\left(\mathrm{CO}_{3}\right)_{2}+2 \mathrm{CO}_{2}+2 \mathrm{H}_{2} \mathrm{O} \Leftrightarrow \mathrm{Ca}^{2+}+\mathrm{Mg}^{2+}+4 \mathrm{HCO}_{3}{ }^{-}$

Table 4

Pearson correlation coefficients of major hydrochemical parameters in confined groundwater.

\begin{tabular}{|c|c|c|c|c|c|c|c|c|c|c|}
\hline & $\mathrm{EC}^{\mathrm{a}}$ & $\mathrm{pH}$ & $\mathrm{K}^{+}$ & $\mathrm{Na}^{+}$ & $\mathrm{Ca}^{2+}$ & $\mathrm{Mg}^{2+}$ & $\mathrm{Cl}^{-}$ & $\mathrm{SO}_{4}^{2-}$ & $\mathrm{HCO}_{3}^{-}$ & $\mathrm{NO}_{3}^{-}$ \\
\hline $\mathrm{EC}^{\mathrm{a}}$ & 1.00 & & & & & & & & & \\
\hline $\mathrm{pH}$ & $-0.43^{* *}$ & 1.00 & & & & & & & & \\
\hline $\mathrm{K}^{+}$ & $0.50^{* * *}$ & $-0.29^{* *}$ & 1.00 & & & & & & & \\
\hline $\mathrm{Na}^{+}$ & $0.79^{* *}$ & -0.08 & $0.25^{*}$ & 1.00 & & & & & & \\
\hline $\mathrm{Ca}^{2+}$ & $0.84^{* *}$ & $-0.53^{* *}$ & $0.57^{* *}$ & $0.39^{* *}$ & 1.00 & & & & & \\
\hline $\mathrm{Mg}^{2+}$ & $0.93^{* *}$ & $-0.51^{* *}$ & $0.53^{* *}$ & $0.66^{* *}$ & $0.83^{* *}$ & 1.00 & & & & \\
\hline $\mathrm{Cl}^{-}$ & $0.94^{* *}$ & $-0.37^{* *}$ & $0.40^{* * *}$ & $0.79^{* *}$ & $0.80^{* *}$ & $0.85^{* *}$ & 1.00 & & & \\
\hline $\mathrm{SO}_{4}^{2-}$ & $0.90^{* *}$ & $-0.39^{* *}$ & $0.28^{* *}$ & $0.72^{* *}$ & $0.79^{* *}$ & $0.84^{* *}$ & $0.95^{* *}$ & 1.00 & & \\
\hline $\mathrm{HCO}_{3}^{-}$ & $0.83^{* *}$ & $-0.37^{* *}$ & $0.62^{* *}$ & $0.77^{* *}$ & $0.60^{* *}$ & $0.83^{* *}$ & $0.72^{* *}$ & $0.60^{* *}$ & 1.00 & \\
\hline $\mathrm{NO}_{3}^{-}$ & $0.51^{* *}$ & $-0.39^{* *}$ & 0.08 & 0.10 & $0.68^{* *}$ & $0.49^{* *}$ & $0.52^{* *}$ & $0.59^{* *}$ & 0.07 & 1.00 \\
\hline
\end{tabular}

All concentrations (except as noted) are in $\mathrm{mg} / \mathrm{L}$. $\mathrm{pH}$ is in standard units.

a Electrical conductivity $(\mu \mathrm{S} / \mathrm{cm})$.

** Correlation is significant at the 0.01 level (2-tailed).

* Correlation is significant at the 0.05 level (2-tailed). 
(a)

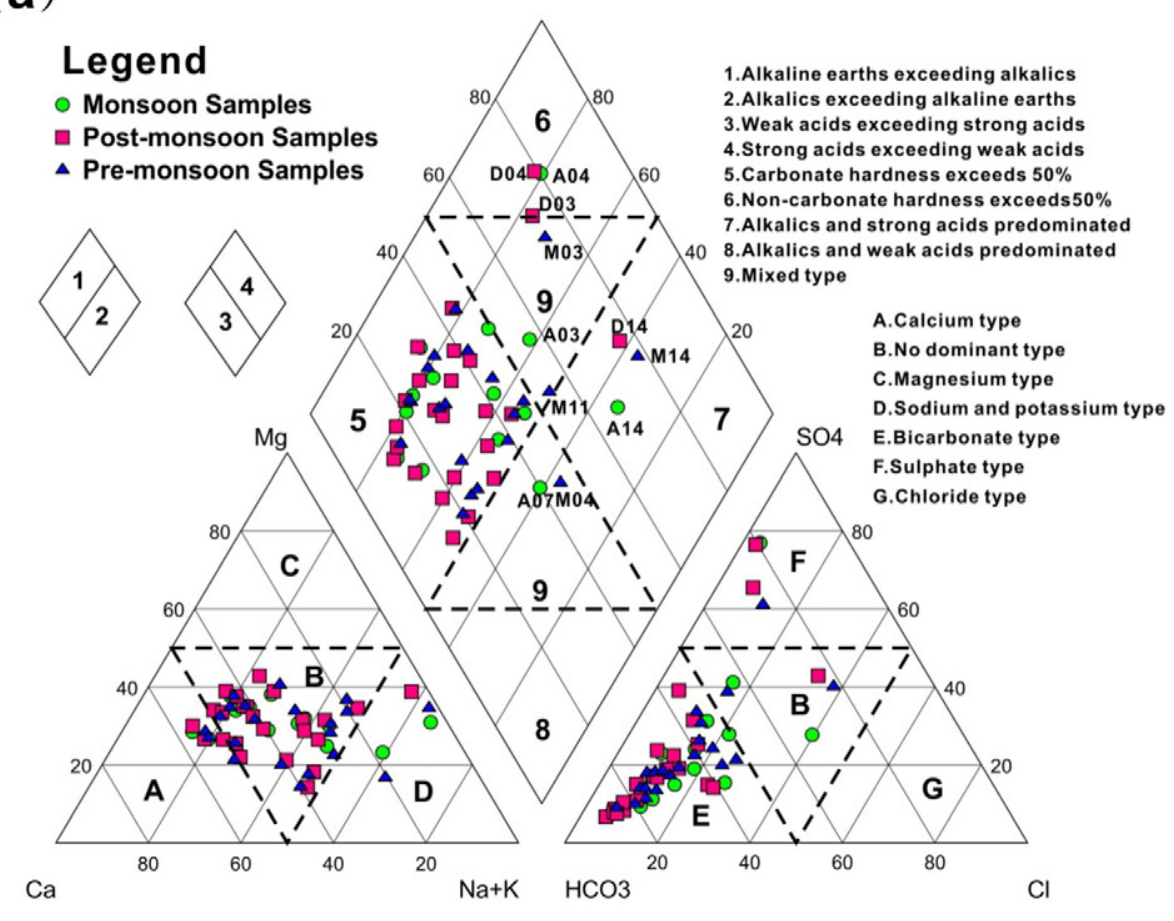

(b)

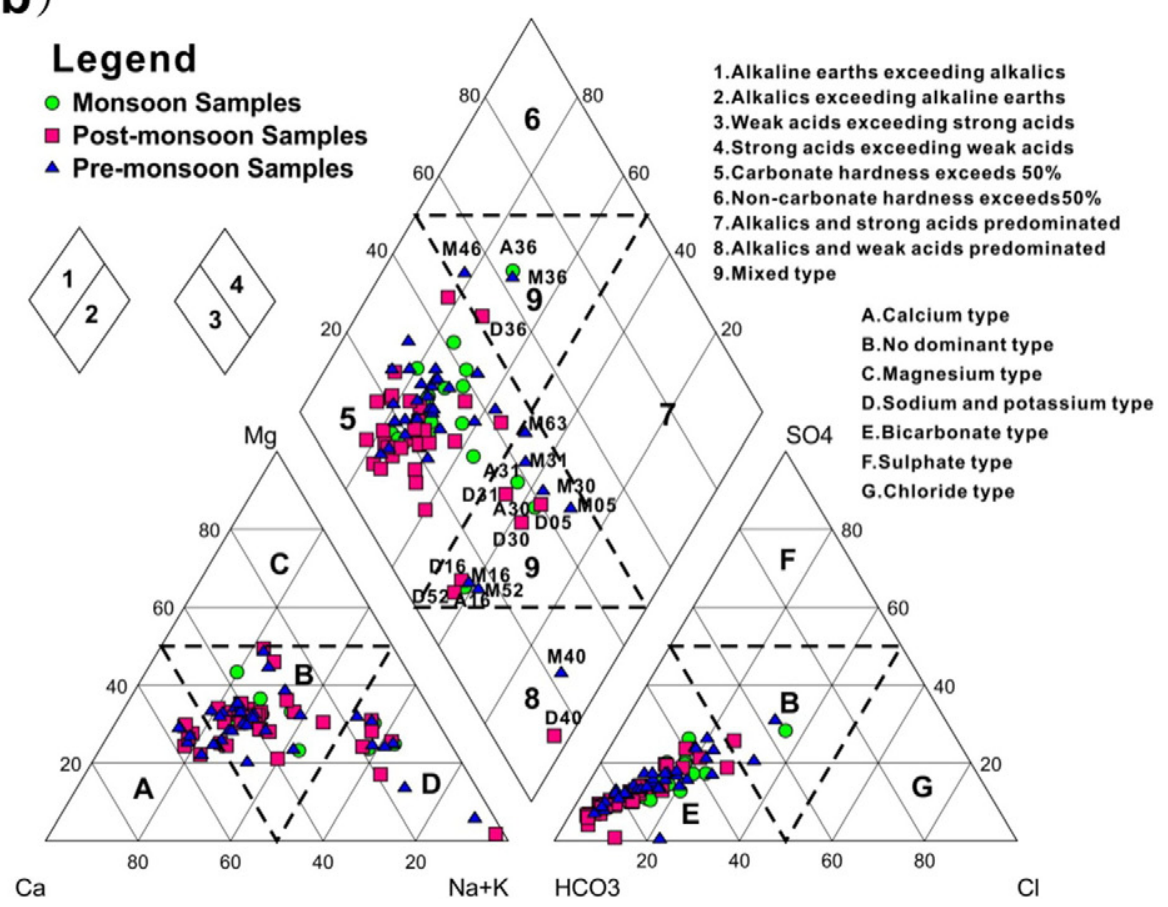

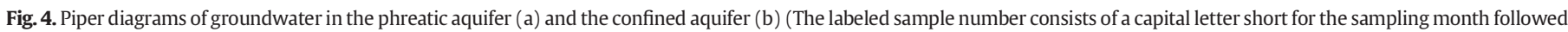
by digit for site number. For example, "A14" means sample from well 14 in August; "D14" means sample from well 14 in December; "M14" means sample from well 14 in May.).

Ionic ratios have been useful in providing an insight into the geochemical processes controlling the changes in water quality. The molar ratio $\mathrm{Na}^{+} / \mathrm{Cl}^{-}$ranged from 1.26 to 6.93 with an average value of 3.19 in the unconfined aquifer and varied from 0.63 to 15.97 with an average value of 3.50 in the confined aquifer, respectively (Fig. 5a). $\mathrm{Cl}^{-}$is well correlated with $\mathrm{Na}^{+}$, suggesting that the dissolution of halite may be the major source of $\mathrm{Na}^{+}$and $\mathrm{Cl}^{-}$. However, greater $\mathrm{Na}^{+} / \mathrm{Cl}^{-}$ ratio can be attributed to the feldspar weathering and the dissolution of other $\mathrm{Na}$-containing minerals. The relatively high $\mathrm{Na}^{+}$concentration in the groundwater could also be illustrated by cation exchange between $\mathrm{Ca}^{2+}$ or $\mathrm{Mg}^{2+}$ and $\mathrm{Na}^{+}$, as is discussed later.

The relationship between $\left(\mathrm{Ca}^{2+}+\mathrm{Mg}^{2+}\right)$ concentrations versus $\left(\mathrm{HCO}_{3}^{-}+\mathrm{SO}_{4}^{2-}\right)$ concentrations for unconfined or confined groundwater samples will be close to the carbonate and gypsum dissolution line (the $1: 1$ line) if these ions are controlled by carbonate and gypsum equilibrium. Ion exchange tends to shift the points to right due to an excess of $\left(\mathrm{HCO}_{3}^{-}+\mathrm{SO}_{4}^{2-}\right)$ (Belkhiri et al., 2011). If reverse ion exchange is the process, it will shift the points to the left due to a large excess of 


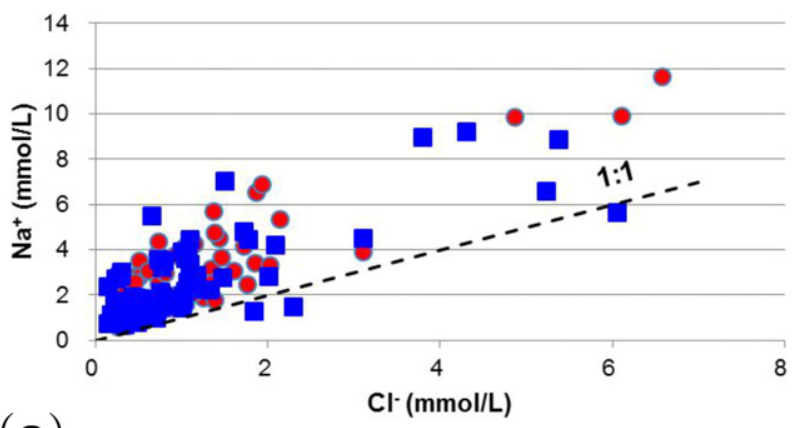

(a)

- Unconfined groundwater $\quad$ Confined groundwater

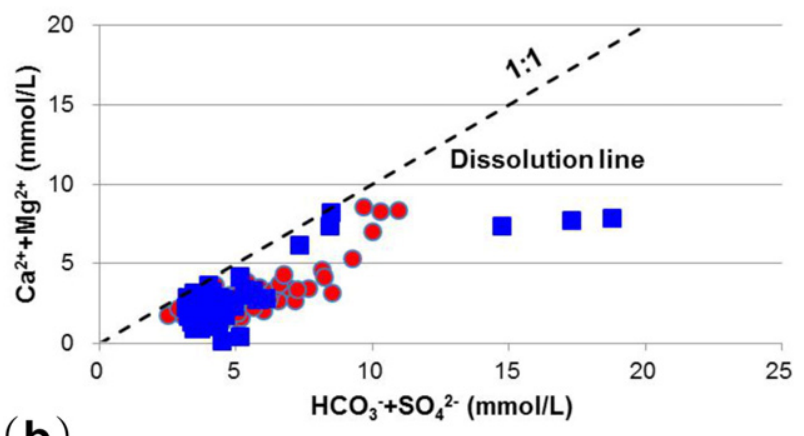

(b)

- Unconfined groundwater $\quad$ Confined groundwater

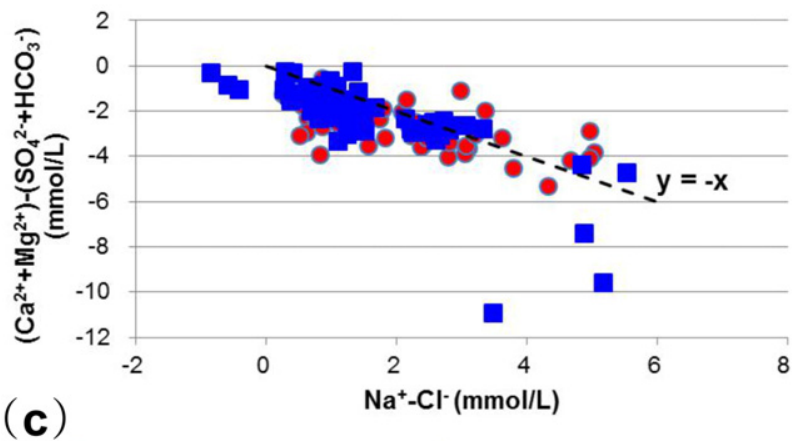

- Unconfined groundwater $\quad$ Confined groundwater

Fig. 5. Plots of $\mathrm{Na}^{+}$versus $\mathrm{Cl}^{-}$(a) and $\left(\mathrm{Ca}^{2+}+\mathrm{Mg}^{2+}\right)$ versus $\left(\mathrm{HCO}_{3}^{-}+\mathrm{SO}_{4}^{2-}\right)$ (b), the relationship between main cation and anion concentration differences illustrating cation exchange in groundwater samples (c), expressed in $\mathrm{mmol} / \mathrm{L}$

$\left(\mathrm{Ca}^{2+}+\mathrm{Mg}^{2+}\right)$ over $\left(\mathrm{HCO}_{3}^{-}+\mathrm{SO}_{4}^{2-}\right)$. The plot of $\left(\mathrm{Ca}^{2+}+\mathrm{Mg}^{2+}\right)$ versus $\left(\mathrm{HCO}_{3}^{-}+\mathrm{SO}_{4}^{2-}\right.$ ) (Fig. 5b) shows that all the groundwater samples are located in the right side due to an excess of $\left(\mathrm{HCO}_{3}^{-}+\mathrm{SO}_{4}^{2-}\right)$, which reflects that ion exchange is one of the geochemical processes in the unconfined or confined groundwater.

The process of cation exchange may be explained by the diagram $\left(\mathrm{Na}^{+}-\mathrm{Cl}^{-}\right)$versus $\left[\left(\mathrm{Ca}^{2+}+\mathrm{Mg}^{2+}\right)-\left(\mathrm{HCO}_{3}^{-}+\mathrm{SO}_{4}^{2-}\right)\right]$ (Fig. $\left.5 \mathrm{c}\right)$, which has been widely used by many scholars (Carol et al., 2013; Huang et al., 2013). The plot examines the excess of $\mathrm{Ca}^{2+}$ and $\mathrm{Mg}^{2+}$ gained or lost from gypsum, calcite and dolomite dissolution/precipitation, and the excess of $\mathrm{Na}^{+}$gained or lost from sodium chlorides dissolution/precipitation, respectively. In this diagram, the groundwater samples are linearly related and scattered along a line of slope -1 , showing an inversely proportional change between $\mathrm{Na}^{+}$and $\mathrm{Ca}^{2+}$ and/or $\mathrm{Mg}^{2+}$. When dissolution of these minerals is enough to explain the hydrochemical composition, all samples should be placed near the point of origin. In the Subei Lake basin, the samples presented a distribution that a decrease in $\left(\mathrm{Ca}^{2+}+\mathrm{Mg}^{2+}-\mathrm{SO}_{4}^{2-}-\mathrm{HCO}_{3}^{-}\right)$was observed with an increase in $\left(\mathrm{Na}^{+}-\mathrm{Cl}^{-}\right)$, which further validates that the cation exchange is one of the main contributors for higher concentration of
$\mathrm{Na}^{+}$in the unconfined or confined groundwater and it is still a key geochemical process of groundwater in the Subei Lake basin under the influence of human activities (Liu et al., 2015). During this process, $\mathrm{Ca}^{2+}$ and $\mathrm{Mg}^{2+}$ in the waters are exchanged with $\mathrm{Na}^{+}$previously adsorbed on the surface of minerals in the aquifer matrix.

\subsubsection{Speciation-solubility calculations}

Speciation-solubility calculations provided the saturation indexes (SI) of several mineral phases (calcite, dolomite, gypsum and halite) and the $\mathrm{CO}_{2}(\mathrm{~g})$ partial pressure in the different samples of the Subei Lake basin (Fig. 6). In this study, the geochemical software PHREEQC (Parkhurst and Appelo, 2004) was used to calculate the saturation indices with respect to gypsum, halite, calcite and dolomite. When the groundwater is saturated with some mineral, SI equals zero; positive values of SI represent oversaturation, and negative values show undersaturation (Appelo and Postma, 1994; Drever, 1997).

Fig. 6 shows the plots of SI versus the electrical conductivity (EC) for all the groundwater samples. Groundwater was highly undersaturated with respect to gypsum and halite (Fig. $6 \mathrm{~A}$ and B). In the phreatic aquifer, the SI of gypsum and halite range from -2.67 to -0.65 and -8.46 to -5.80 with averages -1.93 and -7.32 , respectively. In confined aquifer, the SI values of gypsum and halite vary from -4.8 to -1.1 and -8.61 to -6.03 with averages -2.28 and -7.55 . It shows that these minerals are anticipated to dissolve in groundwater. However, groundwater was oversaturated with respect to calcite and dolomite (Fig. 6C and D). For unconfined groundwater, the calculated values of SI for calcite and dolomite oscillate between -0.59 and $1.20,-1.16$ and 2.64 with averages 0.60 and 1.07 , respectively. For confined groundwater, the calculated values of SI for calcite and dolomite fluctuate between 0.02 and $1.50,-0.13$ and 2.83 with averages 0.53 and 0.91 . Overall, no significant differences were observed between the unconfined and confined waters. Most of groundwater samples were in equilibrium or oversaturated with calcite and dolomite, indicating that the major carbonate minerals may have affected the chemical composition of groundwater in the Subei Lake basin. In addition, calcite and dolomite SI values were independent of EC, whereas gypsum and halite SI values tend to increase with EC, pointing to the dissolution of gypsum and halite as one of the reasons for the increase of salinity. The results show that the groundwater may well produce the precipitation of calcite and dolomite. Due to the existence of abundant carbonate minerals in the aquifer system, saturation of calcite and dolomite could be attained quickly.

The partial pressure of $\mathrm{CO}_{2}(\mathrm{~g})$ shows few differences between the unconfined groundwater (average value: $10^{-2.72} \mathrm{~atm}$ ) and the confined groundwater (average value: $10^{-2.79} \mathrm{~atm}$ ). Fig. 6E indicates that the $\mathrm{pCO}_{2}$ values are negatively correlated with $\mathrm{pH}$ values, the partial pressure values of $\mathrm{CO}_{2}$ decrease as $\mathrm{pH}$ values increase (Adams et al., 2001; Rightmire, 1978). Feldspars are common in the Cretaceous strata and the following reaction possibly occurs (Hou et al., 2008).

$\mathrm{Na}_{2} \mathrm{Al}_{2} \mathrm{Si}_{6} \mathrm{O}_{16}+2 \mathrm{H}_{2} \mathrm{O}+\mathrm{CO}_{2} \rightarrow \mathrm{Na}_{2} \mathrm{CO}_{3}+\mathrm{H}_{2} \mathrm{Al}_{2} \mathrm{Si}_{2} \mathrm{O}_{8}+\mathrm{H}_{2} \mathrm{O}+4 \mathrm{SiO}_{2}$

In this reaction, the consumption of $\mathrm{CO}_{2}$ can result in the increase of the concentration of $\mathrm{Na}^{+}$and $\mathrm{HCO}_{3}^{-}$. As a result, partial pressure of $\mathrm{CO}_{2}$ will decrease and the $\mathrm{pH}$ will increase. The same happens in the Habor Lake basin of the Ordos Plateau (Yin et al., 2009). A pattern of lower $\mathrm{CO}_{2}$ with higher SI for calcite was observed (Fig. 6F), suggesting these groundwater samples may probably have precipitated calcite and lost $\mathrm{CO}_{2}$. In summary, the results obtained by the saturation indexes and the $\mathrm{pCO}_{2}$ validated the geochemical processes inferred previously, especially with respect to the dissolution of gypsum, halite and feldspars, calcite and dolomite precipitation. 


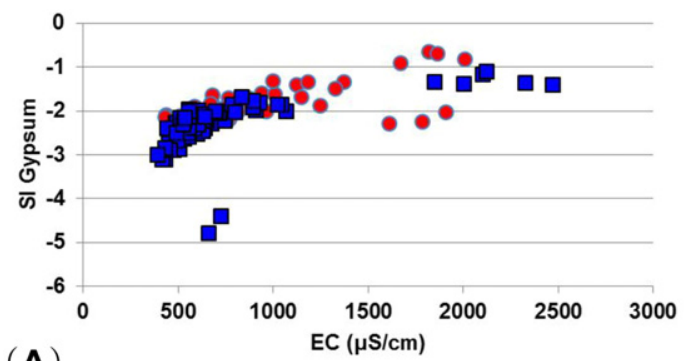

(A)

- Unconfined groundwater $\quad$ Confined groundwater

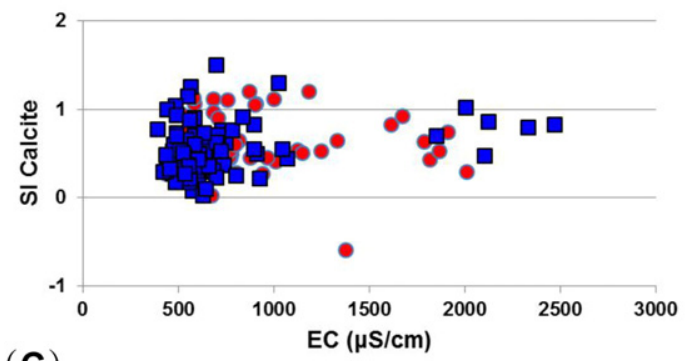

(C)

- Unconfined groundwater aConfined groundwater

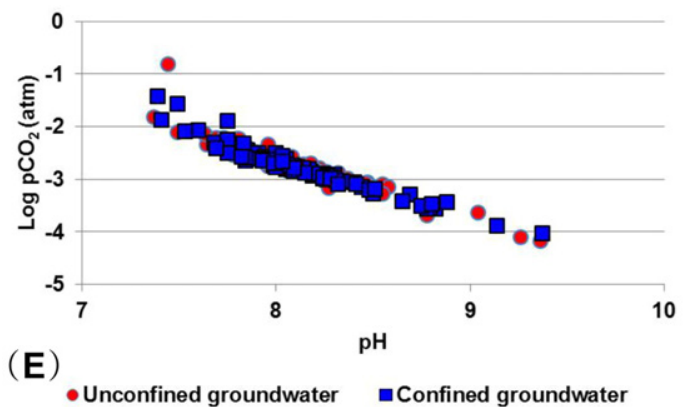

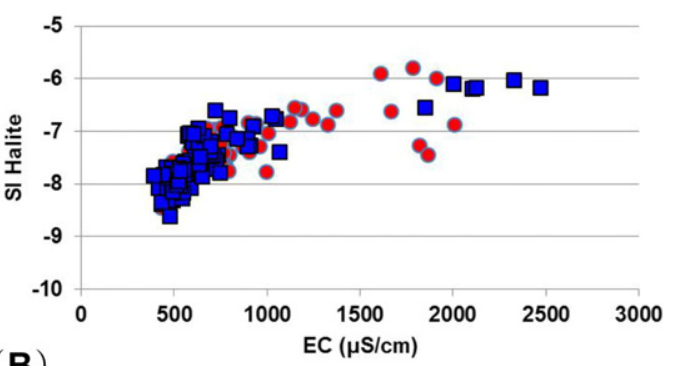

(B)

- Unconfined groundwater $\quad$ Confined groundwater

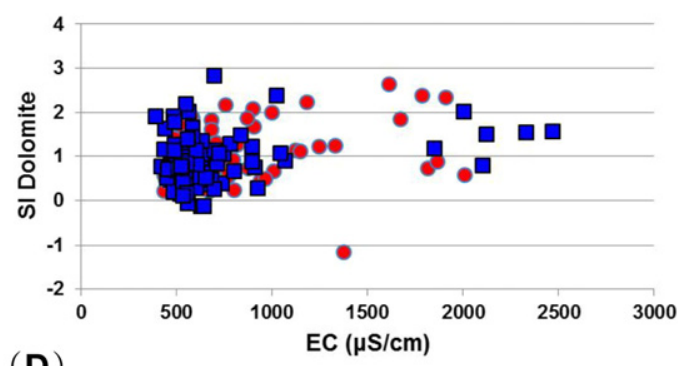

(D)

- Unconfined groundwater $\quad$ Confined groundwater

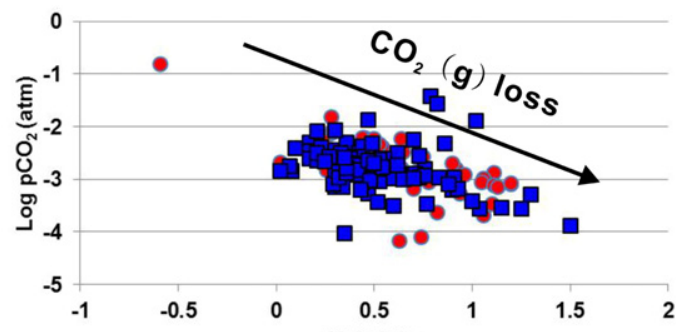

(F)

- Unconfined groundwater aConfined groundwater

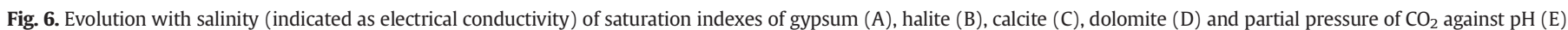
Partial pressure of $\mathrm{CO}_{2}$ against calcite saturation index $(\mathrm{F})$.
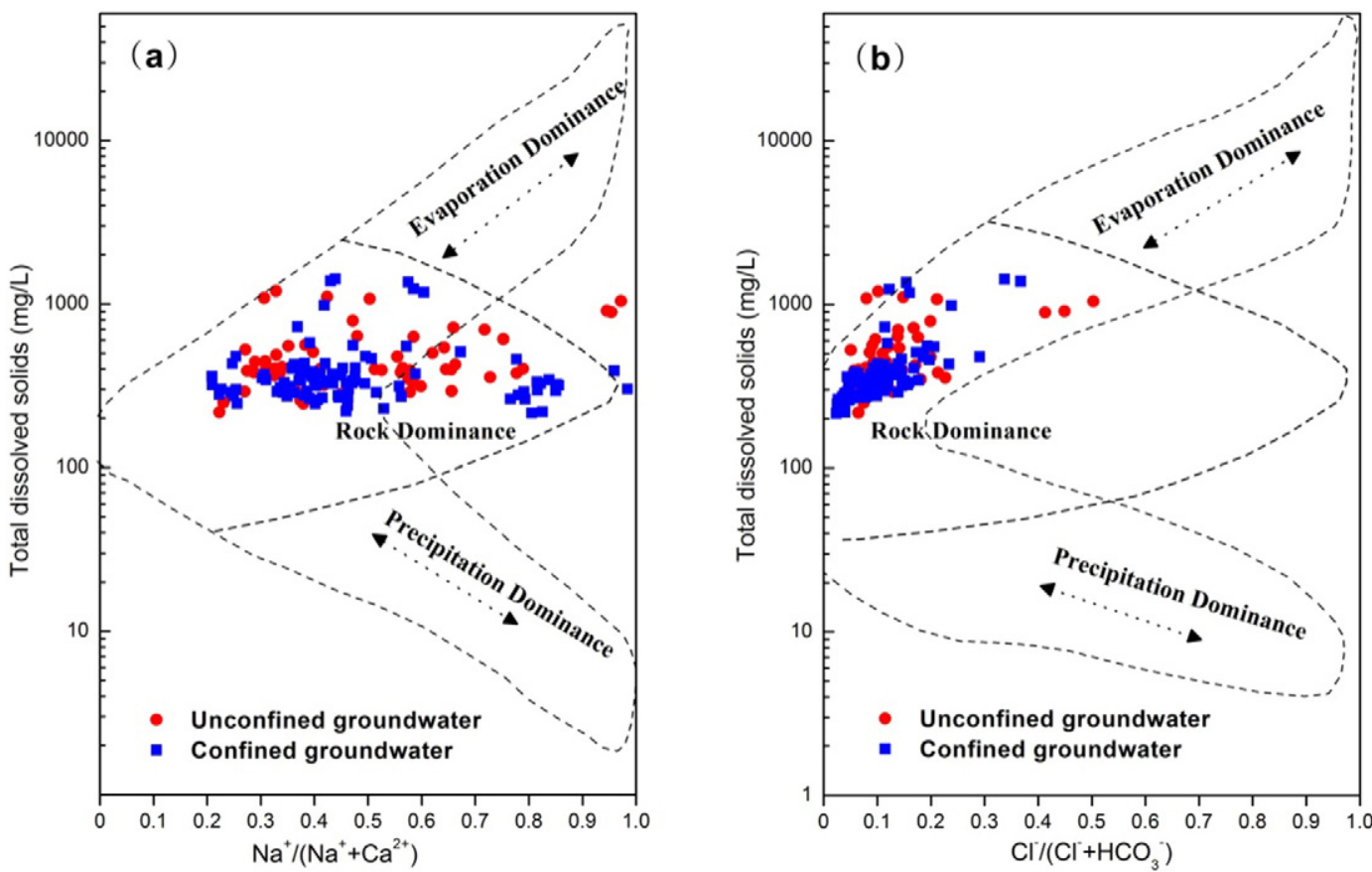

Fig. 7. Gibbs diagrams of groundwater samples in the Subei Lake basin: (a) TDS vs. $\mathrm{Na}^{+} /\left(\mathrm{Na}^{+}+\mathrm{Ca}^{2+}\right),(\mathrm{b}) \mathrm{TDS}_{\mathrm{vs}} \mathrm{Cl}^{-} /\left(\mathrm{Cl}^{-}+\mathrm{HCO}_{3}^{-}\right)$. 


\subsubsection{Formation mechanisms of groundwater chemistry}

The soluble ions in natural waters mainly derive from the rock and soil weathering (Lasaga et al., 1994), anthropogenic input, and partly from the precipitation input. The Gibbs diagrams have been widely used to establish the relationship of groundwater composition and aquifer lithological characteristics (Feth and Gibbs, 1971; Yang et al., 2012). Gibbs (1970) proposed two diagrams to assess dominant effects of precipitation, rock weathering, or evaporation on geochemical evolution of groundwater in semi-arid and arid regions. The diagrams show the weight ratios of $\mathrm{Na}^{+} /\left(\mathrm{Na}^{+}+\mathrm{Ca}^{2+}\right)$ and $\mathrm{Cl}^{-} /\left(\mathrm{Cl}^{-}+\mathrm{HCO}_{3}^{-}\right)$ against TDS, and three distinct fields such as precipitation dominance, evaporation dominance and rock-water interaction dominance areas constitute the segments in the Gibbs diagram (Gibbs, 1970). The distributed characteristic of samples in Fig. 7 shows that rock weathering is the predominant mechanism in the geochemical evolution of the groundwater regardless of the unconfined or confined groundwater in the study area.

It should be noted that no matter the phreatic aquifer or confined aquifer, the weight ratio of $\mathrm{Na}^{+} /\left(\mathrm{Na}^{+}+\mathrm{Ca}^{2+}\right)$ spreads from low to high without great variation of TDS, which indicated that cation exchange also played an important role by increasing $\mathrm{Na}^{+}$and decreasing $\mathrm{Ca}^{2+}$ under the background of rock dominance. During the cation exchange process, the TDS values do not change obviously because $2 \mathrm{mmol} / \mathrm{L}$ of $\mathrm{Na}^{+}$is exchanged with $1 \mathrm{mmol} / \mathrm{L} \mathrm{Ca}^{2+}$, and the weight of $1 \mathrm{mmol} / \mathrm{L}$ of $\mathrm{Ca}^{2+}(40 \mathrm{mg} / \mathrm{L})$ is nearly equal to that of $2 \mathrm{mmol} / \mathrm{L} \mathrm{of} \mathrm{Na}^{+}(46 \mathrm{mg} / \mathrm{L})$.

\subsection{Anthropogenic factors affecting groundwater chemistry}

\subsubsection{The impact of intensive groundwater exploitation on groundwater} chemistry

The intensive groundwater exploitation from Haolebaoji waterworks has exerted significant effects on groundwater system and caused a series of changes in aquifer units since 2006. Groundwater flow direction has been changed drastically and depression cones of groundwater level also occurred in the study area (Wang et al., 2010). The hydrochemical situation of groundwater is likely to be altered concomitant with the changes in hydrodynamic conditions of groundwater due to water abstraction for regional development.

(1) Before the operation of Haolebaoji waterworks, the hydrochemical characteristic of the phreatic aquifer was almost entirely dominated by natural factors and the hydrochemical types were regularly distributed in the form of annular stripes centering on the Subei Lake and Kuisheng Lake. Groundwater anions were dominated by $\mathrm{HCO}_{3}^{-}$and the cations were dominated by $\mathrm{Ca}^{2+}, \mathrm{Mg}^{2+}$ or $\mathrm{Na}^{+}$. The main hydrochemical facies were $\mathrm{Ca}-\mathrm{HCO}_{3}, \mathrm{Ca}-\mathrm{Mg}-\mathrm{HCO}_{3}, \mathrm{Ca}-\mathrm{Na}-\mathrm{HCO}_{3}, \mathrm{Na}-\mathrm{Mg}-\mathrm{HCO}_{3}, \mathrm{Na}-\mathrm{HCO}_{3}$, $\mathrm{Na}-\mathrm{Mg}-\mathrm{HCO}_{3}-\mathrm{SO}_{4}, \mathrm{Na}-\mathrm{HCO}_{3}-\mathrm{SO}_{4}$, and $\mathrm{Na}-\mathrm{HCO}_{3}-\mathrm{Cl}$. As is shown in Fig. 8a, the hydrochemical facies of groundwater were $\mathrm{Ca}-\mathrm{HCO}_{3}, \mathrm{Ca}-$ $\mathrm{Mg}-\mathrm{HCO}_{3}, \mathrm{Ca}-\mathrm{Na}-\mathrm{HCO}_{3}$ in the surrounding highland where the depth to water table was relatively deeper. These hydrochemical types with low TDS can be explained by the good hydrodynamic conditions in the highland such as relatively faster flow velocity, the strong lixiviation and mixture, etc. However, groundwater with $\mathrm{Na}-\mathrm{Mg}-\mathrm{HCO}_{3}-\mathrm{SO}_{4}$, Na$\mathrm{HCO}_{3}-\mathrm{SO}_{4}, \mathrm{Na}-\mathrm{HCO}_{3}-\mathrm{Cl}$ types can be observed in the lowland located in the center of the study area. These types with high TDS can be attributed to relatively poor hydrodynamic conditions including relatively slow, even stagnant flow state, the strong evaporation due to relatively shallower water table in the lowland, and a longer time for water-rock interaction etc. Each of annular stripes represents the spatial distribution of each of hydrochemical types in groundwater, which was the consequence of natural geochemical evolution along groundwater flow path.

However, the hydrochemical facies of unconfined groundwater have been changed to a certain extent since the Haolebaoji waterworks came into use at 2006. In the anthropogenically disturbed groundwater environment, $60 \%$ of 25 sampling sites have been transformed into different
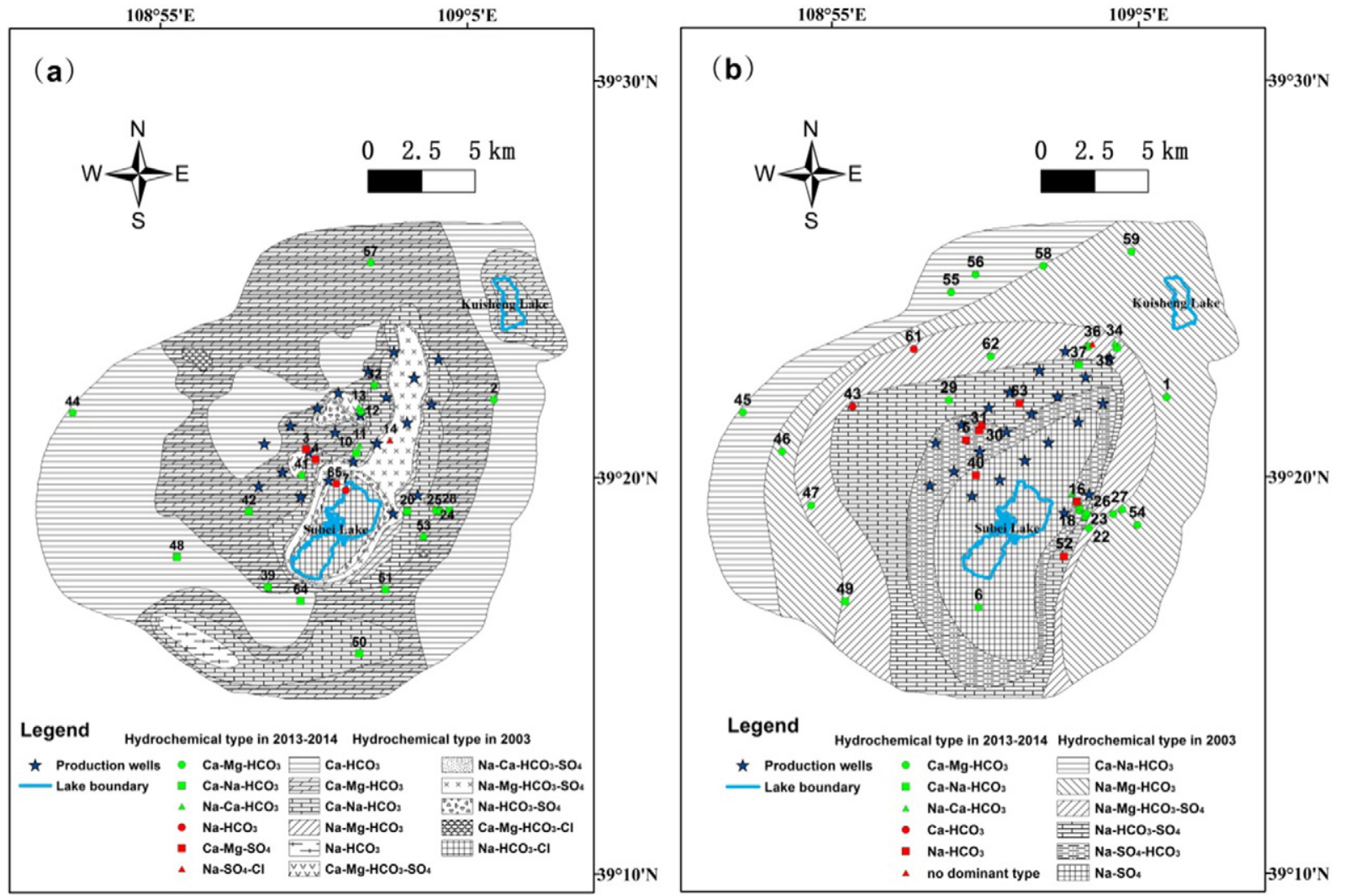

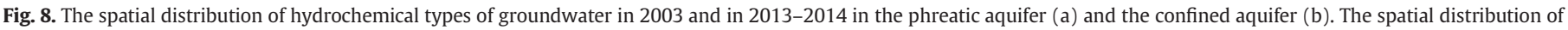

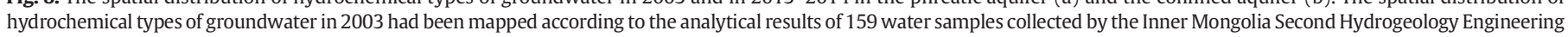
Prospecting Institute. 
hydrochemical types at the present stage (2013-2014). In the area of groundwater with $\mathrm{Ca}-\mathrm{HCO}_{3}$ type in $\mathrm{BO}$ (Fig. 8a), part of groundwater (such as wells $44,48,64$ ) is transformed into $\mathrm{Ca}-\mathrm{Mg}-\mathrm{HCO}_{3}$ or $\mathrm{Ca}-\mathrm{Na}-$ $\mathrm{HCO}_{3}$ types in PO. Although calcium is still the major cation of these groundwater samples, it is very likely that $\mathrm{Ca}^{2+}$ is gradually replaced by $\mathrm{Na}^{+}$or $\mathrm{Mg}^{2+}$ due to accelerated cation exchange. As a result, the percentage of $\mathrm{Ca}^{2+}$ in the total cationic concentrations has been decreased. Part of groundwater with $\mathrm{Ca}-\mathrm{Mg}-\mathrm{HCO}_{3}$ in $\mathrm{BO}$ (including wells 39, 42, 51 ) is changed into $\mathrm{Ca}-\mathrm{Na}-\mathrm{HCO}_{3}$ type in $\mathrm{PO}$ as a result of accelerated groundwater mineralization caused by the changes in hydrodynamic conditions. Moreover, the rest of the wells (such as wells 3, 4, 7, 11, $12,13,14,24,65$ ) where hydrochemical facies have been changed are all distributed around the production wells and the Subei Lake. It should be noted that the predominant anions in groundwater samples from wells 3, 4 and 14 have changed from $\mathrm{HCO}_{3}^{-}$to $\mathrm{SO}_{4}^{2-}$ and $\mathrm{Cl}^{-}$indicative of groundwater deterioration. Given that the relative stability of hydrogeological settings and climatic factors during the period from 2003 to 2014, only the intensive groundwater exploitation from production wells is the main factor that disturbs the groundwater chemistry. Therefore, large-scale groundwater pumping behavior is mainly responsible for the local changes in hydrochemical facies of unconfined groundwater.

(2) All the production wells are screened within the confined aquifer, the behaviors of groundwater pumping from the production wells can exert a direct impact on the confined aquifer. The hydrochemical facies of groundwater will be changed in response to the drastic changes in hydrodynamic conditions. Similar to that of the phreatic aquifer, the hydrochemical types of confined groundwater in BO displayed an obvious regularity in the form of annular stripes spatially. The hydrochemical types evolved from $\mathrm{Ca}-\mathrm{Na}-\mathrm{HCO}_{3}$ and $\mathrm{Na}-\mathrm{Mg}-\mathrm{HCO}_{3}$ types with low TDS in the highland, through $\mathrm{Na}-\mathrm{Mg}-\mathrm{HCO}_{3}-\mathrm{SO}_{4}$ and $\mathrm{Na}-\mathrm{HCO}_{3}-\mathrm{SO}_{4}$ types with moderate TDS in the transitional area, to $\mathrm{Na}-\mathrm{SO}_{4}-\mathrm{HCO}_{3}$ and $\mathrm{Na}-\mathrm{SO}_{4}$ types with high TDS in the lowland along the groundwater flow path in BO (Fig. 8b). However, at present, the hydrochemical types of confined groundwater have been changed entirely due to the strong interference from groundwater withdrawal of this waterworks. The total groundwater samples from the confined aquifer collected during the three campaigns have been transformed into different hydrochemical facies.

In the highland, groundwater samples with $\mathrm{Ca}-\mathrm{Na}-\mathrm{HCO}_{3}, \mathrm{Na}-\mathrm{Mg}-$ $\mathrm{HCO}_{3}$ types have been transformed into $\mathrm{Ca}-\mathrm{Mg}-\mathrm{HCO}_{3}$ type. Groundwater pumping from the production wells may be responsible for this variation of groundwater chemistry. The confined aquifer was recharged by the upper phreatic aquifer in the highland in BO, however, nowadays, the increasingly bigger differences between the piezometric levels and the corresponding water table in the highland have resulted in a larger flux of downward leakage from unconfined groundwater into the confined groundwater via uncontinuous aquitard due to the abstraction of confined groundwater. As a result, confined groundwater with original $\mathrm{Ca}-\mathrm{Na}-\mathrm{HCO}_{3}, \mathrm{Na}-\mathrm{Mg}-\mathrm{HCO}_{3}$ types fully mixed with unconfined groundwater with $\mathrm{Ca}-\mathrm{HCO}_{3}, \mathrm{Ca}-\mathrm{Mg}-\mathrm{HCO}_{3}$ types and produced the confined groundwater samples with $\mathrm{Ca}-\mathrm{Mg}-\mathrm{HCO}_{3}$ type nowadays (Fig. 8b). It is confirmed that the confined aquifer was recharged by the downward leakage from unconfined aquifer in the highland from a hydrochemical view.

In the transitional area, the hydrochemical facies of groundwater have shifted from $\mathrm{Na}-\mathrm{Mg}-\mathrm{HCO}_{3}-\mathrm{SO}_{4}$ or $\mathrm{Na}-\mathrm{HCO}_{3}-\mathrm{SO}_{4}$ to $\mathrm{Ca}-\mathrm{Mg}-$ $\mathrm{HCO}_{3}, \mathrm{Ca}-\mathrm{HCO}_{3}, \mathrm{Na}-\mathrm{HCO}_{3}, \mathrm{Ca}-\mathrm{Na}-\mathrm{HCO}_{3}$ and no dominant type. It should be noted that unconfined groundwater with $\mathrm{Ca}-\mathrm{Mg}-\mathrm{HCO}_{3}, \mathrm{Ca}-$ $\mathrm{HCO}_{3}, \mathrm{Na}-\mathrm{HCO}_{3}, \mathrm{Ca}-\mathrm{Na}-\mathrm{HCO}_{3}$ types was just underlain by confined groundwater with $\mathrm{Na}-\mathrm{Mg}-\mathrm{HCO}_{3}-\mathrm{SO}_{4}$ or $\mathrm{Na}-\mathrm{HCO}_{3}-\mathrm{SO}_{4}$ types, and the induced downward leakage from upper unconfined aquifer promoted the formation of the current hydrochemical patterns.

Similarly, groundwater with $\mathrm{Na}-\mathrm{SO}_{4}-\mathrm{HCO}_{3}, \mathrm{Na}-\mathrm{SO}_{4}$ types in $\mathrm{BO}$, which is located in the lowland adjacent to the Subei Lake, was transformed into $\mathrm{Ca}-\mathrm{Mg}-\mathrm{HCO}_{3}, \mathrm{Ca}-\mathrm{Na}-\mathrm{HCO}_{3}$ and $\mathrm{Na}-\mathrm{HCO}_{3}$ in PO. The phreatic aquifer was recharged by the underlying confined aquifer in the lowland in BO, however, at present, the opposite situation that the confined aquifer received the downward leakage from the upper unconfined aquifer took place in PO.

Therefore, the strong mixture between unconfined groundwater and confined groundwater, especially a large influx of downward leakage from the upper unconfined aquifer into the confined aquifer, played a vital role in the variation of hydrochemical facies. But after all, the intensive groundwater exploitation from Haolebaoji waterworks is still the fundamental cause for the significantly macroscopic changes in geochemical evolution of groundwater.

\subsubsection{Nitrate contamination}

Agricultural practices result in non-point source pollution of groundwater and the effects of these practices accumulate with time (Liu et al., 2005). Non-point sources of nitrogen from agricultural practices include fertilizer and manure application (Chowdary et al., 2005). It should be noted that in the study area, the nitrate concentrations in the confined aquifer varied within a larger range from 0.8 to $385.3 \mathrm{mg} / \mathrm{L}$ than that in the phreatic aquifer $(0.6-147.4 \mathrm{mg} / \mathrm{L})$. The average value of the nitrate concentrations in confined aquifer $(58.7 \mathrm{mg} / \mathrm{L})$ was much larger than that in the phreatic aquifer $(27.9 \mathrm{mg} / \mathrm{L})$. About $17 \%$ of the unconfined groundwater samples showed nitrate concentrations exceeding the maximum admissible nitrate concentration limit in drinking water (50 mg/L) (WHO, 2004). However, nearly half of the confined groundwater samples exceeded the corresponding standard surprisingly. In general, the unconfined aquifer is more vulnerable to nitrate contamination than the confined aquifer. However, the opposite situation takes place in the Subei Lake basin and the confined aquifer is more heavily contaminated from the nitrate than the phreatic aquifer. The interesting phenomenon can be well explained by the following possible reasons: (1) the confined aquifer is likely to chronically subjected to the nitrate plume migration from adjacent basin located in the recharge area outside the study area, given that agricultural practices or a plenty of manure from animals (cattle, sheep, etc.) is widespread in Ordos basin (Dong et al., 2010); (2) the nitrate contaminants may be more difficult to be removed in the confined aquifer than the phreatic aquifer, due to relatively stagnant hydrodynamics and lack of microbes caused by relatively closed environment; (3) the intensive groundwater pumping has disturbed the original hydrodynamic conditions (Wang et al., 2010), and further changed the fact that the phreatic aquifer is more vulnerable to nitrate contamination. A large amount of downward leakage from the upper unconfined aquifer into the confined aquifer may be responsible for the more nitrate enrichment in the confined aquifer.

Given the severity of the nitrate contamination in the confined aquifer, the significantly positive correlation between $\mathrm{NO}_{3}^{-}$and $\mathrm{Ca}^{2+}$ or $\mathrm{SO}_{4}^{2-}$ can be only observed in the confined aquifer. In the confined aquifer, $\mathrm{Ca}^{2+}$ is well correlated with $\mathrm{NO}_{3}^{-}$with a correlation coefficient of 0.68 (Table 4), which may be simply explained by the fact that nitrates appear elevated values in the sandstone aquifer where calcium prevails. Another possibility that both elements are possibly derived from the excessive use of $\mathrm{Ca}\left(\mathrm{NO}_{3}\right)_{2}$-fertilizers is excluded given that calcium is not favorable for soil amendments, unless soils are acidified. Moreover, the significantly positive correlation between $\mathrm{NO}_{3}^{-}$and $\mathrm{SO}_{4}^{2-}$ with a correlation coefficient of 0.59 (Table 4 ) highlights that both elements are possibly used in the form of $\left(\mathrm{NH}_{4}\right)_{2} \mathrm{SO}_{4}$-fertilizers in the study area (Dong et al., 2010). Under the oxic condition, as the main component of fertilizers, $\mathrm{NH}_{4}^{+}$is easily oxidized to $\mathrm{NO}_{3}^{-}$by the nitrification process as is shown in the following equations:

$$
\begin{aligned}
& \mathrm{NH}_{4}^{+}+1.5 \mathrm{O}_{2} \Leftrightarrow \mathrm{NO}_{2}{ }^{-}+\mathrm{H}_{2} \mathrm{O}+2 \mathrm{H}^{+} \\
& \mathrm{NO}_{2}{ }^{-}+0.5 \mathrm{O}_{2} \Leftrightarrow \mathrm{NO}_{3}{ }^{-}
\end{aligned}
$$

Therefore, the nitrate contamination is a result of the local hydrogeological settings coupled with the traditional flood irrigation 
and the complete lack of environmental awareness about the overfertilization.

\section{Conclusions}

The Subei Lake basin lies in an economically and ecologically important area, where the rapid economic development and intensive anthropogenic activities have collectively affected the geochemical evolution of groundwater resources (qualitatively and quantitatively) due to a very large increase in water demands for industrial usage. In this semi-arid region, the problems associated with groundwater quality issues are of growing concern, since the intensive groundwater pumping has led to serious environmental consequences, which threaten the vulnerable ecosystems. Therefore, sustainable management of groundwater resources in the Subei Lake basin requires a good understanding of both groundwater circulation patterns and hydrologic/hydrochemical processes that affect water chemistry. The combination of techniques employed in this study (i.e. piper diagram, ionic ratios, Gibbs diagrams, correlation analysis etc.) provided an efficient way for analyzing a high-dimensional hydrochemical dataset.

At present, the major hydrochemical facies in unconfined groundwater are $\mathrm{Ca}-\mathrm{Mg}-\mathrm{HCO}_{3}, \mathrm{Ca}-\mathrm{Na}-\mathrm{HCO}_{3}, \mathrm{Na}-\mathrm{Ca}-\mathrm{HCO}_{3}, \mathrm{Na}-\mathrm{HCO}_{3}$, $\mathrm{Ca}-\mathrm{Mg}-\mathrm{SO}_{4}$ and $\mathrm{Na}-\mathrm{SO}_{4}-\mathrm{Cl}$ types. The main hydrochemical facies in confined groundwater are $\mathrm{Ca}-\mathrm{Mg}-\mathrm{HCO}_{3}, \mathrm{Ca}-\mathrm{Na}-\mathrm{HCO}_{3}, \mathrm{Na}-\mathrm{Ca}-\mathrm{HCO}_{3}$, $\mathrm{Ca}-\mathrm{HCO}_{3}$ and $\mathrm{Na}-\mathrm{HCO}_{3}$ types. The chemical constituents of confined groundwater have undergone relatively more obvious seasonal variation than that of unconfined groundwater. Among the natural factors, the major geochemical processes are the dissolution/precipitation of gypsum, halite, feldspar, calcite and dolomite. Overall, the rock weathering absolutely predominates the geochemical evolution of groundwater in conjunction with the cation exchange. In the study area, anthropogenic activities responsible for the deterioration in quality of groundwater resources can be classified as: (1) groundwater overexploitation; (2) excessive application of fertilizers in agricultural areas. The accelerated groundwater mineralization caused by the intensive groundwater pumping is mainly responsible for the local changes in hydrochemical facies of unconfined groundwater. The strong mixture between unconfined groundwater and confined groundwater, especially a large influx of downward leakage from the upper unconfined aquifer into the confined aquifer as a consequence of intensive groundwater pumping, played a vital role in the fundamental variation of hydrochemical facies in confined aquifer. Additionally, the nitrate contamination is a result of the local hydrogeological settings coupled with the traditional flood irrigation and the complete lack of environmental awareness about the over-fertilization.

The results of this study are promising and suggest that combination of these techniques can be successfully applied to decipher underlying natural and anthropogenic processes creating these water types and characterization of geochemical evolution of groundwater. To protect the vulnerable ecosystem and the vital groundwater resources from further deterioration, the government agencies should adopt strategies that could include: regulating the amount and type of fertilizers applied to agricultural soils, monitoring of groundwater pumping rates in industrial zones, and developing a groundwater monitoring network for assessment of the groundwater quality periodically.

\section{Acknowledgments}

This research was supported by the State Basic Research Development Program (973 Program) of China (grant no. 2010CB428805) and Greenpeace East Asia. The authors are grateful to our colleagues for their assistance in data collection and field investigation. Special thanks go to the editor and the anonymous reviewers for their critical reviews and valuable suggestions.

\section{References}

Adams, S., Titus, R., Pietersen, K., Tredoux, G., Harris, C., 2001. Hydrochemical characteristics of aquifers near Sutherland in the Western Karoo, South Africa. J. Hydrol. 241, 91-103.

Amalfitano, S., Bon, A.D., Zoppini, A., Ghergo, S., Fazi, S., Parrone, D., et al., 2014. Groundwater geochemistry and microbial community structure in the aquifer transition from volcanic to alluvial areas. Water Res. 65, 384-394.

Ammar, F.H., Chkir, N., Zouari, K., Hamelin, B., Deschamps, P., Aigoun, A., 2014. Hydrogeochemical processes in the Complexe Terminal aquifer of southern Tunisia: an integrated investigation based on geochemical and multivariate statistical methods. J. Afr. Earth Sci. 100, 81-95.

Appelo, C.A.J., Postma, D., 1994. Geochemistry, Groundwater and Pollution. AA Balkema, Rotterdam.

Belkhiri, L., Boudoukha, A., Mouni, L., Baouz, T., 2011. Statistical categorization geochemical modeling of groundwater in Ain Azel plain (Algeria). J. Afr. Earth Sci. 59, 140-148.

Boulton, A.J., 2009. Recent progress in the conservation of groundwaters and their dependent ecosystems. Aquat. Conserv. Mar. Freshwat. Ecosyst. 19, 731-735.

Carol, E., Mas-Pla, J., Kruse, E., 2013. Interaction between continental and estuarine waters in the wetlands of the northern coastal plain of Samborombón Bay, Argentina. Appl. Geochem. 34, 152-163.

Carucci, V., Petitta, M., Aravena, R., 2012. Interaction between shallow and deep aquifers in the Tivoli Plain (Central Italy) enhanced by groundwater extraction: a multiisotope approach and geochemical modeling. Appl. Geochem. 27, 266-280.

Chowdary, V.M., Rao, N.H., Sarma, P.B.S., 2005. Decision support framework for assessment of non-point-source pollution of groundwater in large irrigation projects. Agric. Water Manag. 75, 194-225.

Dai, S.F., Ren, D.Y., Chou, C.L., Li, S.S., Jiang, Y.F., 2006. Mineralogy and geochemistry of the No. 6 coal (Pennsylvanian) in the Junger Coalfield, Ordos Basin, China. Int. J. Coal Geol. $66,253-270$.

Di Lorenzo, T., Cifoni, M., Lombardo, P., Fiasca, B., Galassi, D.M.P., 2015. Ammonium threshold values for groundwater quality in the EU may not protect groundwater fauna: evidence from an alluvial aquifer in Italy. Hydrobiologia 743, 139-150.

Dong, W., Lin, X., Zhang, B., Hu, Y., Jiao, X., 2010. Hydrochemical distribution law and pollutant source of shallow groundwater in the south of Sulige, Ordos. J. Arid Land Resour. Environ. 24, 103-108 (in Chinese).

Drever, J.I., 1997. The Geochemistry of Natural Waters: Surface and Groundwater Environments. Prentice Hall, New Jersey.

Feth, J.H., Gibbs, R.J., 1971. Mechanisms controlling world water chemistry: evaporationcrystallization process. Science 172, 871-872.

Gibbs, R.J., 1970. Mechanisms controlling world water chemistry. Science 170, $1088-1090$

Güler, C., Kurt, M.A., Alpaslan, M., Akbulut, C., 2012. Assessment of the impact of anthropogenic activities on the groundwater hydrology and chemistry in Tarsus coastal plain (Mersin, SE Turkey) using fuzzy clustering, multivariate statistics and GIS techniques. J. Hydrol. 414-415, 435-451.

Hancock, P.J., Boulton, A.J., Humphreys, W.F., 2005. Aquifers and hyporheic zones: towards an ecological understanding of groundwater. Hydrogeol. J. 13, 98-111.

He, J., Ma, J., Zhang, P., Tian, L., Zhu, G., Edmunds, W.M., et al., 2012. Groundwater recharge environments and hydrogeochemical evolution in the Jiuquan Basin, Northwest China. Appl. Geochem. 27, 866-878.

Hou, G., Zhao, M., Wang, Y., 2006. Groundwater Investigation in the Ordos Basin. China Geological Survey, Beijing (in Chinese).

Hou, G., Liang, Y., Su, X., Zhao, Z., Tao, Z., Yin, L., et al., 2008. Groundwater systems and resources in the Ordos Basin, China. Acta Geol. Sin. 82, 1061-1069.

Huang, G., Sun, J., Zhang, Y., Chen, Z., Liu, F., 2013. Impact of anthropogenic and natural processes on the evolution of groundwater chemistry in a rapidly urbanized coastal area, South China. Sci. Total Environ. 463-464, 209-221.

Iepure, S., Meffe, R., Carreño, F., Rasines, R.L., de Bustamante, I., 2014. Geochemical, geological and hydrological influence on ostracod assemblages distribution in the hyporheic zone of two Mediterranean rivers in central Spain. Int. Rev. Hydrobiol. 99, 435-449.

Lasaga, A.C., Soler, J.M., Ganor, J., Burch, T.E., Nagy, K.L., 1994. Chemical-weathering rate laws and global geochemical cycles. Geochim. Cosmochim. Acta 58, 2361-2386.

Lawrence, A.R., Gooddy, D.C., Kanatharana, P., Ramnarong, V., Meesilp, W., Lawrence, A.R. et al., 2000. Groundwater evolution beneath a rapidly developing city in South East Asia. Hydrogeol. J. 8, 564-575.

Lin, C.Y., Abdullah, M.H., Praveena, S.M., Yahaya, A.H.B., Musta, B., 2012. Delineation of temporal variability and governing factors influencing the spatial variability of shallow groundwater chemistry in a tropical sedimentary island. J. Hydrol. 432, 26-42.

Liu, A., Ming, J., Ankumah, R.O., 2005. Nitrate contamination in private wells in rural Alabama, United States. Sci. Total Environ. 346, 112-120.

Liu, F., Song, X., Yang, L., Zhang, Y., Han, D., Ma, Y., et al., 2015. Identifying the origin and geochemical evolution of groundwater using hydrochemistry and stable isotopes in the Subei Lake basin, Ordos energy base, Northwestern China. Hydrol. Earth Syst. Sci. 19, 551-565

Parkhurst, D.L., Appelo, C., 2004. PHREEQC2 user's manual and program. Water-Resources Investigations Report. US Geological Survey, Denver, Colorado.

Piper, A.M., 1953. A Graphic Procedure in the Geochemical Interpretation of Water Analysis. US Department of the Interior, Geological Survey, Water Resources Division, Ground Water Branch, Washington.

Rightmire, C.T., 1978. Seasonal-variation in $\mathrm{pCO}_{2}$ and ${ }^{13} \mathrm{C}$ content of soil atmosphere. Water Resour. Res. 14, 691-692.

Sbarbati, C., Colombani, N., Mastrocicco, M., Aravena, R., Petitta, M., 2015. Performance of different assessment methods to evaluate contaminant sources and fate in a coastal aquifer. Environ. Sci. Pollut. Res. 1-13. 
Wang, W., Yang, G., Wang, G., 2010. Groundwater numerical model of Haolebaoji well field and evaluation of the environmental problems caused by exploitation. Southto-North Water Transf. Water Sci. Technol. 8, 36-41 (in Chinese).

Wang, P., Yu, J., Zhang, Y., Liu, C., 2013. Groundwater recharge and hydrogeochemical evolution in the Ejina Basin, northwest China. J. Hydrol. 476, 72-86.

Wang, S., Tang, C., Song, X., Wang, Q., Zhang, Y., Yuan, R., 2014. The impacts of a linear wastewater reservoir on groundwater recharge and geochemical evolution in a semi-arid area of the Lake Baiyangdian watershed, North China Plain. Sci. Total Environ. 482-483, 325-335.
WHO, 2004. Guidelines for Drinking-Water Quality. Third ed. RecommendationsWorld Health Organization, Geneva.

Yang, L., Song, X., Zhang, Y., Yuan, R., Ma, Y., Han, D., et al., 2012. A hydrochemical framework and water quality assessment of river water in the upper reaches of the Huai River Basin, China. Environ. Earth Sci. 67, 2141-2153.

Yin, L., Hou, G., Dou, Y., Tao, Z., Li, Y., 2009. Hydrogeochemical and isotopic study of groundwater in the Habor Lake Basin of the Ordos Plateau, NW China. Environ. Earth Sci. 64, 1575-1584. 